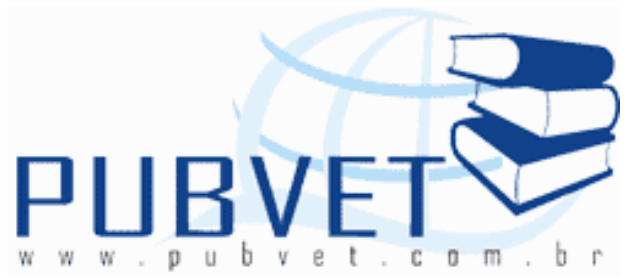

PUBVET, Publicações em Medicina Veterinária e Zootecnia.

\title{
Senescência, remoção, translocação de nutrientes e valor nutritivo em gramíneas tropicais
}

Tiago Adriano Simioni ${ }^{1}$, Alvair Hoffmann ${ }^{1}$, Fagner Junior Gomes ${ }^{1}$, Claudio Jonasson Mousquer ${ }^{2}$, Ubiara Henrique Gomes Teixeira ${ }^{1}$, Geferson Antonio Fernandes ${ }^{3}$, Leonardo Antonio Botini ${ }^{1}$ e Diego Cordeiro de Paula ${ }^{1}$

${ }^{1}$ Mestrandos em Zootecnia da UFMT, campus de Sinop-MT, Brasil

${ }^{2}$ Mestrando em Ciência Animal da UFMT/FAMEVZ, campus de Cuiabá-MT, Brasil

${ }^{3}$ Zootecnista, UFMT, campus de Sinop-MT

\section{Resumo}

Apesar de o Brasil deter um dos maiores rebanhos bovinos comerciais do mundo, cerca de 209 milhões de cabeça (IBGE, 2011), observa-se que a taxa de lotação média é muito baixa, resultando em produtividade inferior ao potencial do setor pecuário. Dentre os vários fatores que contribuem para essa baixa produtividade, pode-se destacar a estacionalidade na oferta de alimento como um fator agravante para o setor produtivo. Basicamente, em todas as regiões do Brasil, a estacionalidade é caracterizada por variações na disponibilidade e qualidade da forragem em reposta às alterações nas condições climáticas, as quais não permitem que as plantas forrageiras tenham crescimento uniforme durante $o$ ano. A escolha da gramínea forrageira, para formação de uma pastagem, deve ser bastante criteriosa, visando maior 
produtividade de matéria seca e conteúdo de proteína bruta, com equilíbrio estacional e aceitabilidade pelos animais. O manejo da pastagem visa obter equilíbrio entre o rendimento/qualidade da forragem produzida, com a manutenção da composição botânica desejada. Associado a esses fator tem-se a possibilidade de obter bons resultados da produção animal por área. Para obtenção de adequado manejo de pastagem, torna-se necessário conhecer além das características físicas, estruturais e anatômicas das espécies forrageiras, a quantidade de forragem oferecida aos animais e o valor nutritivo, mas também a quantidade de forragem a ser consumida pelo animal e o valor nutritivo da forragem efetivamente consumida.

Palavras-chave: pastagem, fisiologia vegetal, zootecnia

\title{
Senescence, removal, transport of nutrients and nutritional value in tropical grasses
}

\begin{abstract}
Although Brazil holds one of the largest commercial cattle herd in the world, about 209 million head (IBGE, 2011), it is observed that the average stocking rate is very low, resulting in lower potential productivity of the livestock sector. Among the various factors that contribute to this low productivity, can highlight the seasonality in food supply as an aggravating factor for the productive sector. Basically, in all regions of Brazil, seasonality is characterized by variations in the availability and quality of forage in response to changes in climatic conditions which do not allow forage plants have uniform growth throughout the year. The choice of forage grass to form a pasture, must be very careful to increase their productivity of dry matter and crude protein content, with seasonal balance and acceptability by animals. The pasture management aims to achieve balance between the performance / quality of forage produced, maintaining the desired botanical composition. Associated with these factors has been able to obtain good results by field of animal production. To obtain proper pasture management, it is necessary to know
\end{abstract}


SIMIONI, T.A. et al. Senescência, remoção, translocação de nutrientes e valor nutritivo em gramíneas tropicais. PUBVET, Londrina, V. 8, N. 13, Ed. 262, Art. 1743, Julho, 2014.

beyond the physical, structural and anatomical characteristics of forage species, the amount of forage offered to animals and nutritive value, but also the amount of forage being consumed by the animal and nutritional value the forage actually consumed.

Keywords: animal Science, grazing, plant physiology

\section{INTRODUÇÃO}

A pecuária brasileira é caracterizada pelo sistema extensivo baseada na utilização das pastagens, as quais representam à fonte mais abundante e econômica na alimentação de ruminantes. Apesar de o Brasil deter um dos maiores rebanhos bovinos comerciais do mundo, cerca de 209 milhões de cabeça (IBGE, 2011), observa-se que a taxa de lotação média é muito baixa, resultando em produtividade inferior ao potencial do setor pecuário.

Dentre os vários fatores que contribuem para essa baixa produtividade, pode-se destacar a estacionalidade na oferta de alimento como um fator agravante para o setor produtivo. Basicamente, em todas as regiões do Brasil, a estacionalidade é caracterizada por variações na disponibilidade e qualidade da forragem em reposta às alterações nas condições climáticas, as quais não permitem que as plantas forrageiras tenham crescimento uniforme durante 0 ano.

As pastagens constituem a base da pecuária brasileira, sendo poderosa ferramenta de redução de custos. Por isso, a utilização e o manejo dessas áreas devem ser realizados de maneira profissional, buscando eficiências ótimas de produção e utilização, e para que os potenciais benefícios a lucratividade do sistema de produção sejam obtidos (Moreno, 2004).

Os solos ocupados por pastagens em geral são marginais quando comparados àqueles usados pela agricultura de grãos, estes solos apresentam problemas de fertilidade natural, acidez, topografia, pedregosidade ou limitações de drenagem (Macedo, 1999).

A área de pastagem cultivada no Brasil, que apresenta melhor qualidade que as nativas, predominante, é do gênero da Brachiaria, sendo $55 \%$ da $B$. 
SIMIONI, T.A. et al. Senescência, remoção, translocação de nutrientes e valor nutritivo em gramíneas tropicais. PUBVET, Londrina, V. 8, N. 13, Ed. 262, Art. 1743, Julho, 2014.

decumbens, $21 \%$ da B. brizantha; $8 \%$ da B. humidícula, e, em seguida, o gênero é o Panicum, sendo $7 \%$ do $P$. maximum cv. Colonião comum, $4 \%$ do $P$. maximum cv. Tanzânia , Tobiatã, Mombaça, etc., 4\% de outros (Andropogon, Hyparrheria, Melinis, Cynodon) (Zimmer et al., 1998). E, no Brasil, cerca de $90 \%$ da carne bovina é produzida em sistemas em que a alimentação do rebanho está baseada exclusivamente em pastagens (Arruda, 1997).

Tendo em vista que as plantas forrageiras são submetidas constantemente ao estresse da colheita, seja pelo pastejo ou pelo corte, há a necessidade de discutir sobre a habilidade dessas plantas para se recuperarem (Nascimento Jr et al., 1993), levando em conta as características fisiológicas da planta e do ambiente ao qual está submetida, para que o manejo possa ser eficiente e não prejudicial à produtividade da planta forrageira.

O manejo racional e efetivo de ecossistemas de pastagens torna-se uma conseqüência da manipulação das atividades fisiológicas dos componentes de cada espécie forrageira, bem como da otimização de seu desempenho ao longo das estações de crescimento (Marshall, 1987), para tanto, torna-se necessário reconhecer a planta forrageira como componente chave do sistema de produção (Da Silva et al., 1998).

A escolha da gramínea forrageira, para formação de uma pastagem, deve ser bastante criteriosa ,visando maior produtividade de matéria seca e conteúdo de proteína bruta, com equilíbrio estacional e aceitabilidade pelos animais (Gerdes, 2000).

O manejo da pastagem visa obter equilíbrio entre o rendimento/qualidade da forragem produzida, com a manutenção da composição botânica desejada. Ao mesmo tempo procura-se obter bons resultados da produção animal por área (Nascimento Jr, et al., 1994a).

Para obtenção de adequado manejo de pastagem, torna-se necessário conhecer além das características físicas, estruturais e anatômicas das espécies forrageiras, a quantidade de forragem oferecida aos animais e o valor nutritivo, mas também a quantidade de forragem a ser consumida pelo animal e o valor nutritivo da forragem efetivamente consumida (Brâncio et al., 2003). 
SIMIONI, T.A. et al. Senescência, remoção, translocação de nutrientes e valor nutritivo em gramíneas tropicais. PUBVET, Londrina, V. 8, N. 13, Ed. 262, Art. 1743, Julho, 2014.

Dado o exposto, objetivou-se descrever e comentar a respeito dos principais processos fisiológicos das plantas forrageiras e suas conseqüências sobre a produtividade.

\section{REVISÃO DA LITERATURA}

\section{GRAMÍNEAS TROPICAIS}

As pastagens apresentam estacionalidade de crescimento durante o ano, todavia atingem, em determinado momento, sua melhor qualidade da dieta de pastejo, dependente das condições de temperatura, luminosidade e disponibilidade hídrica (Vallentine, 1990). A temperatura afeta principalmente o crescimento das plantas no decorrer das estações do ano, com diminuição nos períodos de outono e inverno, que influencia de modo direto e indireto o metabolismo da planta, afetando principalmente a fotossíntese e absorção e translocação dos nutrientes (Silva, 1995; Eastin \& Sullivan, 1984), quando a umidade do solo não é limitante.

Em regiões tropicais, as altas temperaturas e intensidade luminosas favoreciam altas taxas de evapotranspiração e que poderiam produzir "déficit" hídricos estacionais, provocando alterações no desenvolvimento das plantas (Machado et al., 1983).

A luz solar pode afetar o desenvolvimento e o florescimento das gramíneas, de modo que seu efeito poderia ser dividido em três diferentes componentes: resposta ao comprimento de radiação recebida (fotoperiodismo), a qualidade de luz (comprimentos de onda), e a irradiação (energia radiante). Estes três componentes interagem durante todo o crescimento da planta e principalmente no momento de florescimento (Soria, 2002). A produtividade forrageira, acompanhando os índices pluviométricos, pode ser melhor exemplificada a seguir (Figura 1). 


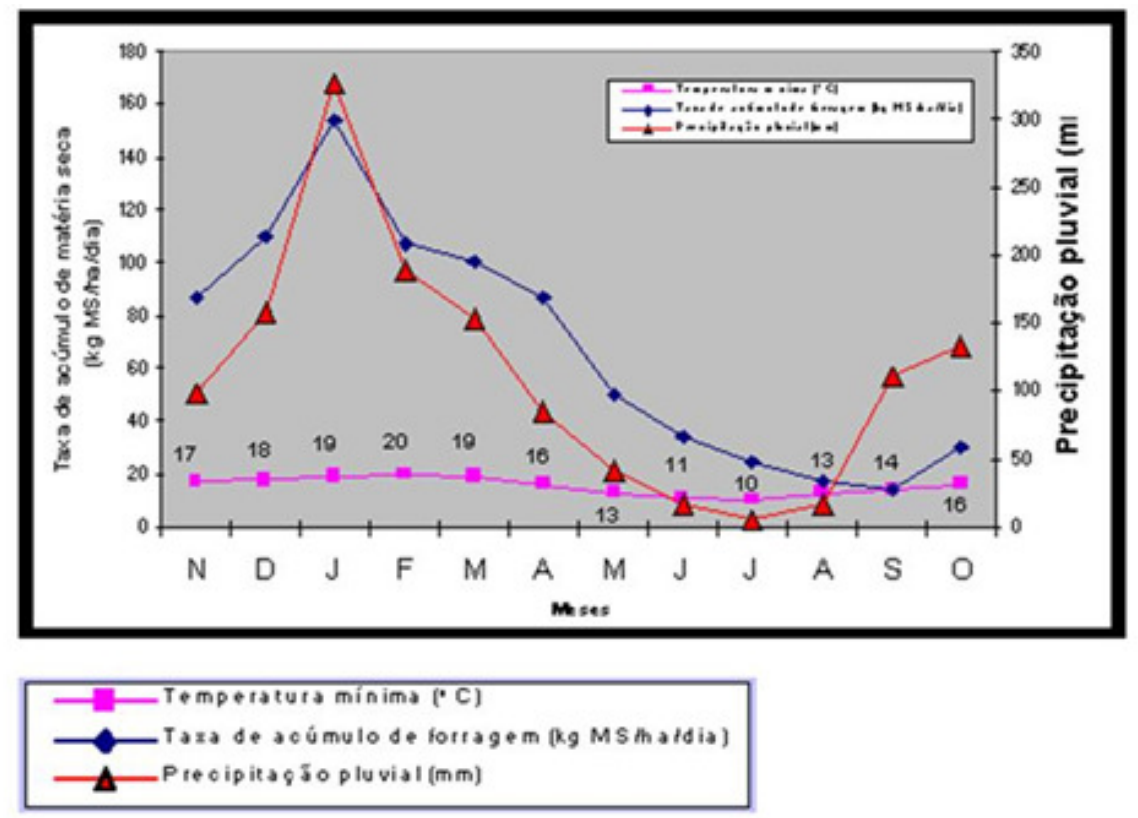

Figura 1 - Médias das taxas mensais de acúmulo de matéria seca (MS) em pastagens de capim-tanzânia, adubado, sem irrigação, em 1995 e 1996, na Embrapa Pecuária Sudeste em São Carlos, SP (Corrêa, 1995).

\section{Condições das pastagens brasileiras}

Parte considerável das pastagens brasileiras apresentam problemas de degradação, o que contribui para a não-sustentabilidade da produção. Dentre os diversos fatores que contribuem para isso, menciona-se entre outros, a queda na fertilidade do solo (Euclides, 2000). Quando a pastagem é utilizada de forma contínua, sem que haja tempo para o restabelecimento de um nível mínimo de reservas através da fotossíntese, as plantas desfolhadas debilitamse e acabam por desaparecer, cedendo lugar às espécies indesejáveis (Rodrigues et al., 1987), dando início ao processo de degradação das pastagens.

Degradação da pastagem está baseada num processo contínuo de alterações da pastagem (Figura 2) que tem início com a queda do vigor e da produtividade da pastagem (Nascimento Jr, et al.,1999). 
SIMIONI, T.A. et al. Senescência, remoção, translocação de nutrientes e valor nutritivo em gramíneas tropicais. PUBVET, Londrina, V. 8, N. 13, Ed. 262, Art. 1743, Julho, 2014.

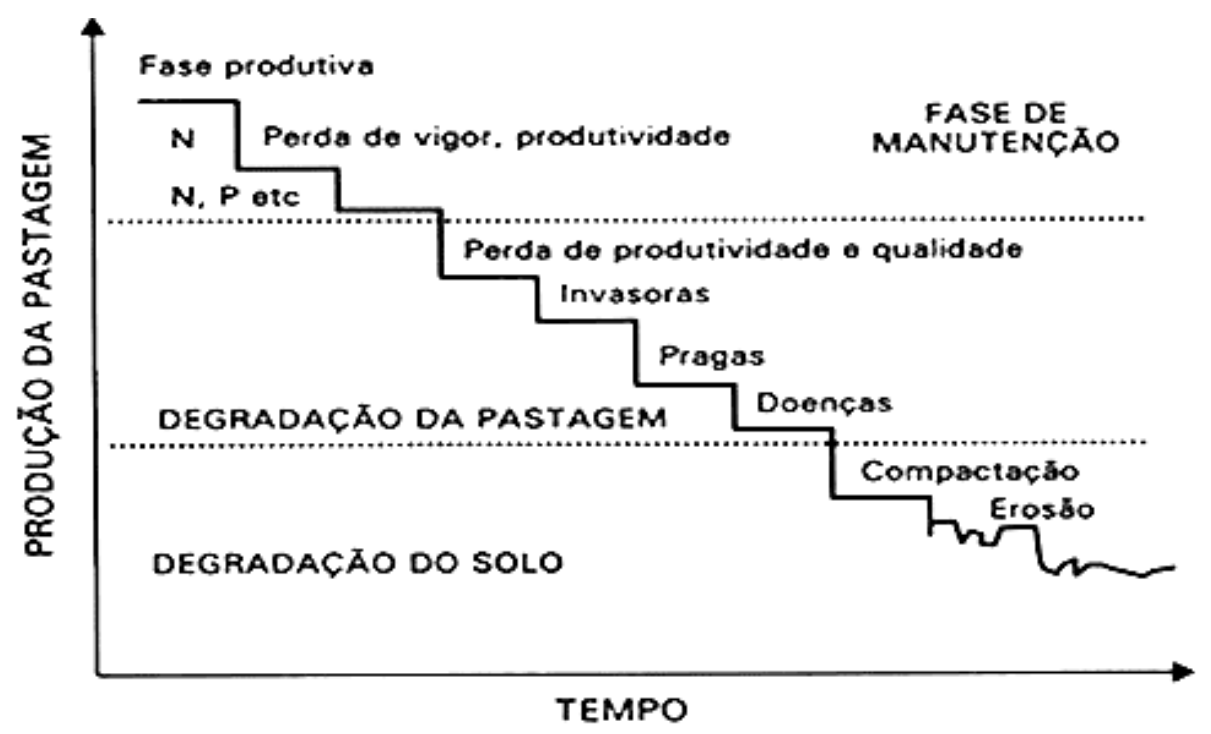

Figura 2 - Representação esquemática do processo de degradação de pastagens em suas diferentes etapas no tempo (Martha Júnior e Vilela, 2002).

No topo estariam as maiores produtividades e, à medida que se descem os degraus com a utilização da pastagem, avança-se no processo de degradação. Até um determinado ponto, ou um certo degrau, haveria condições de se conter a queda de produção e manter a produtividade através de ações mais simples, diretas e com menores custos operacionais. A partir desse ponto, passar-se-ia para o processo propriamente de degradação, em que só ações de recuperação ou de renovação, muitas vezes mais drásticas e dispendiosas apresentariam respostas adequadas. $O$ final do processo culminaria com a ruptura dos recursos naturais, representado pela degradação do solo com alterações em sua estrutura, evidenciado pela compactação e a conseqüente diminuição das taxas de infiltração e capacidade de retenção da água, causando erosão e assoreamento das nascentes de lagos e rios (Macedo, 1999).

\section{DETERMINANTES MORFOFISIOLÓGICOS DE PLANTAS FORRAGEIRAS}

Estudos sobre a morfologia de plantas forrageiras evidenciam que a recuperação de uma pastagem após desfolha, por corte ou pastejo, é influenciada por suas características morfológicas intrínsecas, que são a área 
SIMIONI, T.A. et al. Senescência, remoção, translocação de nutrientes e valor nutritivo em gramíneas tropicais. PUBVET, Londrina, V. 8, N. 13, Ed. 262, Art. 1743, Julho, 2014.

foliar remanescente, os teores de carboidratos não estruturais de reserva, bem como o número de pontos de crescimento capazes de promover a rebrota (Ward \& Blaser, 1961; Gomide, 1973; Jacques, 1973; Rodrigues \& Rodrigues, 1987).

O conhecimento das taxas de aparecimento, alongamento e senescência foliares e de perfilhamento se reveste de fundamental importância para a interpretação do acúmulo de forragem sob um especificado sistema de manejo e do efeito do clima sobre o rendimento forrageiro (Grant \& Marriot, citados por Gomide, 1997).

Com base na necessidade da planta em rebrotar com vigor após a desfolha, os métodos de pastejo devem procurar otimizar a inter-relação entre índice de área foliar (IAF), interceptação luminosa (IL), acúmulo de carboidratos, e crescimento da pastagem. Para uma pastagem formada com plantas forrageiras no estádio de crescimento vegetativo, Lemaire \& Chapman (1996) apontaram que a morfogênese pode ser descrita por três características básicas: 1) taxa de aparecimento de folhas (TAF); 2) taxa de elongação de folhas (TEF); e 3) tempo de vida da folha (Figura 3).

As combinações dessas características morfo-genéticas determinam as principais características estruturais da pastagem (Lemaire \& Chapman, 1996):

1) tamanho da folha: que é determinada pela taxa de aparecimento de folhas e pela taxa de expansão de folhas, uma vez que o tempo de elongação de uma folha depende diretamente do aparecimento da folha subseqüente (Dale, 1982 citado por Lemaire \& Chapman, 1996);

2) densidade de perfilhos: relacionado particularmente com a taxa de aparecimento de folhas, que determina o número potencial de pontos de aparecimento de perfilhos, quando comparadas com aquelas com taxa de aparecimento de folhas reduzida;

3) número de folhas verdes por perfilho: é o produto direto do tempo de vida da folha e da taxa de aparecimento de folhas. 
SIMIONI, T.A. et al. Senescência, remoção, translocação de nutrientes e valor nutritivo em gramíneas tropicais. PUBVET, Londrina, V. 8, N. 13, Ed. 262, Art. 1743, Julho, 2014.

Essas características são determinadas geneticamente, mas podem, no entanto ser influenciadas por variáveis como temperatura, suprimento de nutrientes e disponibilidade de umidade no solo (Fischer e Da Silva, 2001).

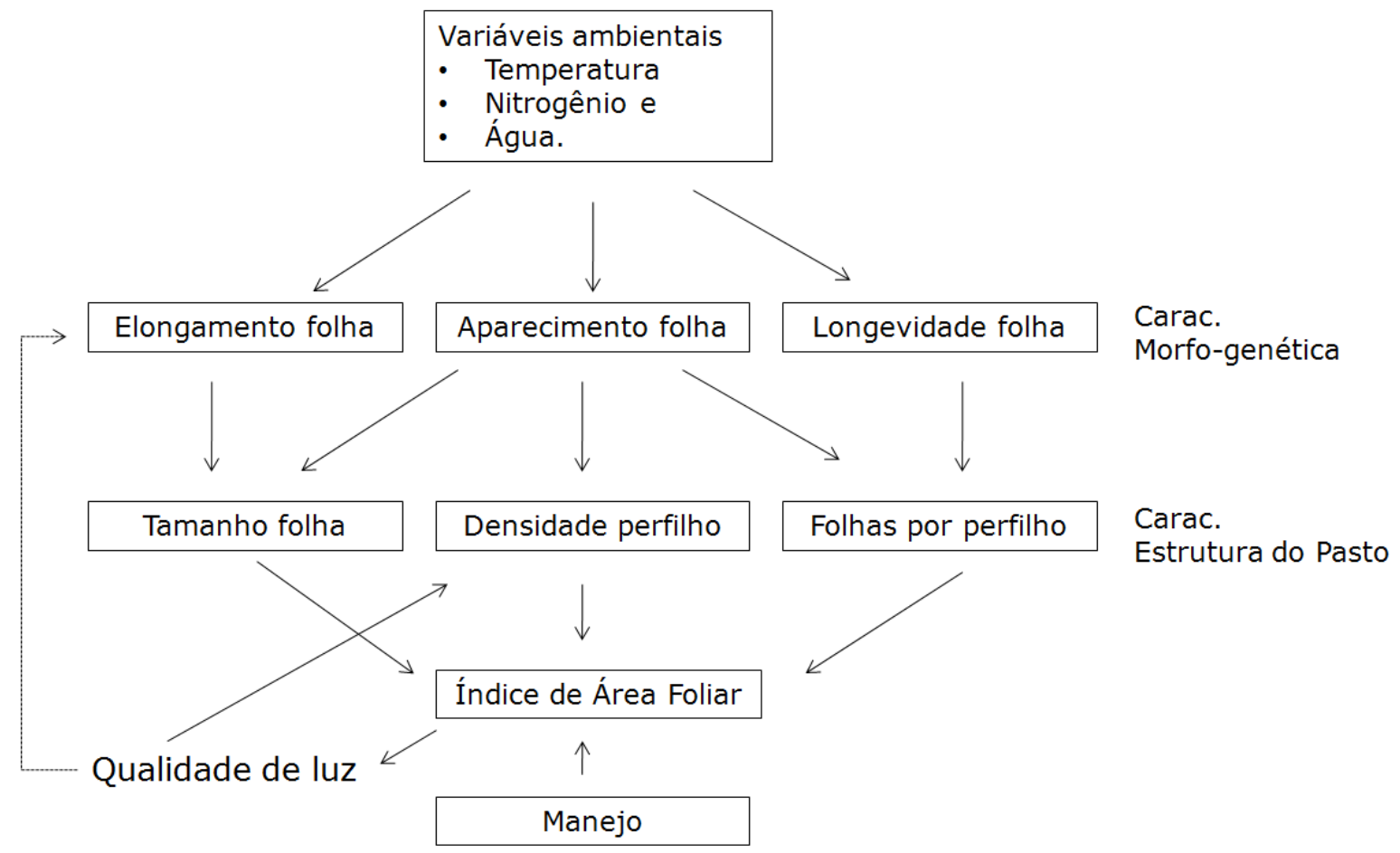

Figura 3 - Relação entre variáveis morfo-genéticas e características estruturais do pasto (Adaptado de Lemaire \& Chapman, 1996).

A combinação dessas três características estruturais da comunidade de plantas dá origem ao índice de área foliar que define a interceptação luminosa realizada pela planta forrageira. Variações no IAF provocam efeito direto na interceptação luminosa, por sua vez podem promover alterações relativamente rápidas na densidade dos perfilhos, podendo ainda agir em menor intensidade e mais em longo prazo nas demais características estruturais e morfogenéticas (Lemaire \& Chapman, 1996).

Em se tratando de plantas individuais, dois tipos de respostas à desfolha podem ser diferenciados: uma resposta fisiológica, oriunda da redução no suprimento de carbono para a planta, devido à perda de parte dos tecidos fotossintetizantes; e uma morfológica, que resulta em modificações na 
alocação do carbono entre os diferentes órgãos de crescimento da planta (folhas, perfilhos, raízes), o que confere às plantas tolerância às desfolhações (Lamaire, 1997). Favaretto (1993) afirmou que, de acordo com a severidade de corte, o estádio de crescimento e o genótipo das plantas, a remoção do ápice ou de todo o caule pode promover ou inibir seu perfilhamento. $O$ pastejo além de reduzir a área foliar total do dossel, altera a estrutura das folhas do dossel e, consequentemente, a capacidade fotossintética das plantas (Briske, 1991, citado por Cavalcanti, 2001).

\section{CONSIDERAÇÕES SOBRE A FOTOSSÍNTESE NA PRODUÇÃO DE GRAMÍNEAS TROPICAIS}

A produção forrageira se baseia na transformação de energia solar em compostos orgânicos pela fotossíntese, onde o carbono, do dióxido de carbono (CO2), na atmosfera, é combinado com água e convertido em carboidratos com a utilização da energia solar (Raven et al., 2001). As condições do meio ambiente em que as plantas são submetidas podem influenciar os principais processos fisiológicos das plantas, como a fotossíntese e a respiração, determinantes da produtividade das plantas.

A síntese de tecido vegetal tem como base carboidratos simples (energia) produzidos via fotossíntese (Figura 4), que é desencadeada quando os cloroplastos dos tecidos das folhas verdes são expostos à luz. Essa energia é utilizada para reduzir o carbono do $\mathrm{CO} 2$ para formação de carboidratos (Hodgson, 1990). 
SIMIONI, T.A. et al. Senescência, remoção, translocação de nutrientes e valor nutritivo em gramíneas tropicais. PUBVET, Londrina, V. 8, N. 13, Ed. 262, Art. 1743, Julho, 2014.

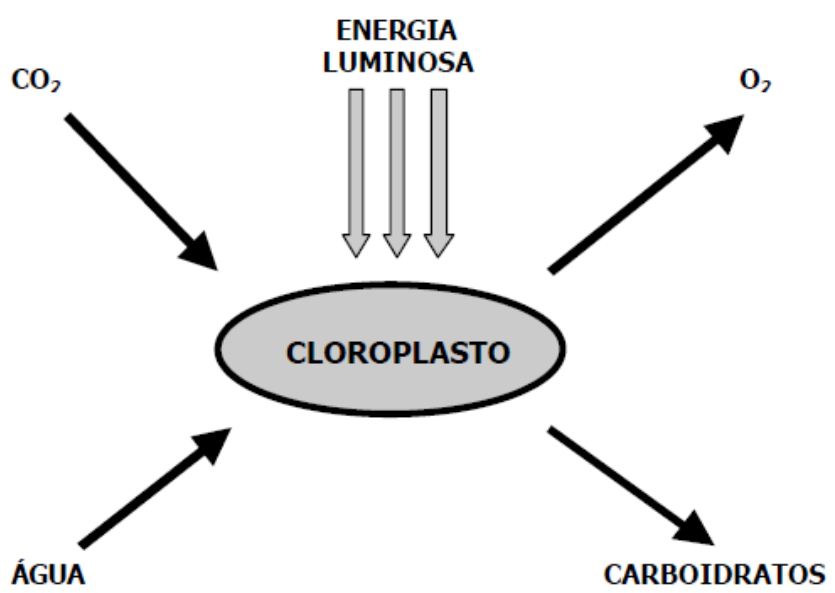

Figura 4 - Esquema simplificado do processo fotossintético (Adaptado de Hodgson, 1990).

A taxa fotossintética da folha determina a quantidade total de carbono fixada disponível para a folha (Taiz \& Zeiger, 1998) e é função de fatores intrínsecos, como o nível de inserção (Ryle \& Powell, 1974) e a idade (Woledge, 1971), e de fatores extrínsecos às folhas, como a irradiância, a água no solo, a temperatura e os nutrientes (Larcher, 1995).

Como resultado desse conjunto de fatores, as folhas de mais alto nível de inserção no perfilho, mais jovens e melhor iluminadas, fotossintetizam mais e geralmente contribuem mais para o pool de fotoassimilados da planta que as folhas mais velhas, de mais baixos níveis de inserção (Robson et al., 1988).

Folhas completamente expandidas fazem fotossíntese com intensidade máxima e os assimilados por elas formados servem não apenas para sua própria manutenção como para atender às necessidades do meristema apical, do sistema radicular e das folhas em formação. A folha cujo limbo está parcialmente exposto, não transloca assimilados para outras partes do perfilho, usando-os para o seu próprio desenvolvimento (Milthorpe \& Davidson, 1966).

Cerca de $90 \%$ da massa seca vegetal são constituídos por compostos oriundos da fotossíntese (Zelitch, 1982) e não parece haver limitações à produção devido as taxas fotossintéticas. O que ocorre mais provavelmente é 
SIMIONI, T.A. et al. Senescência, remoção, translocação de nutrientes e valor nutritivo em gramíneas tropicais. PUBVET, Londrina, V. 8, N. 13, Ed. 262, Art. 1743, Julho, 2014.

que outras variáveis fisiológicas e de ambiente, tais como déficit hídrico e relações fonte-dreno, impõem limites à produção e à produtividade.

\section{REMOÇÃO E TRANSLOCAÇÃO DE NUTRIENTES E FOTOASSIMILADOS}

Segundo Wilhelm e McMaster (1995), crescimento pode ser definido como aumento irreversível na dimensão física de um indivíduo ou órgão, em determinado intervalo de tempo. Por outro lado, desenvolvimento inclui o processo de iniciação de órgãos (morfogênese) até a diferenciação, podendo incluir o processo de senescência. Deste modo, uma definição funcional de desenvolvimento, segundo esses autores, seria o processo em que as plantas, os órgãos ou as células passam por vários estágios, identificáveis, durante o seu ciclo de vida.

A biomassa vegetal pode ser limitada tanto pela produção como pelo uso dos fotoassimilados por parte dos meristemas foliares (Lemaire \& Agnusdei, 1999).

A partição de fotoassimilados acompanha a força do dreno, que é produto de seu tamanho (peso total do tecido do dreno) e de sua atividade (taxa de absorção de assimilados por unidade de peso do tecido) (Taiz \& Zeiger, 1998). Além disso, a distância do dreno à fonte, a competição entre eles e a arquitetura vascular de folhas e colmos têm grande influência sobre a partição de fotoassimilados em plantas intactas, crescendo sob condições nãolimitantes (Chapman et al. 1991a,b; Matthew \& Kemball, 1997). Estudos de partição de fotoassimilados são fundamentais para o entendimento da fisiologia vegetal, pois a dinâmica da relação fonte/dreno varia conforme o meio, o estádio fisiológico da planta e o manejo da cultura.

A folha ao longo do seu desenvolvimento pode ser caracterizada como importadora líquida de assimilados (drenos) e exportadora líquida (fonte). As folhas jovens em crescimento são drenos muito fortes de assimilados e de nutrientes, pois importam mais do que exportam. A medida que vão crescendo, se transformam em fonte, já que exportam mais do que importam. 
SIMIONI, T.A. et al. Senescência, remoção, translocação de nutrientes e valor nutritivo em gramíneas tropicais. PUBVET, Londrina, V. 8, N. 13, Ed. 262, Art. 1743, Julho, 2014.

À semelhança das folhas, as sementes e rizomas são drenos durante a sua formação, e logo após se transformam em fonte, durante a germinação e rebrote, respectivamente. A diferença entre uma folha e um órgão de reserva atuando como fonte, reside no fato de que a folha é um tecido autotrófico e exporta o que produz, enquanto que os órgãos de reserva são heterotróficos e somente re-exportam os assimilados acumulados previamente (remobilização).

As folhas adultas retêm cerca de 10 a $25 \%$ de seus assimilados para sua manutenção, sendo o destino dos assimilados exportados determinado pela idade da folha e pelo seu nível de inserção no perfilho (Ryle, 1970a).

O carbono requerido para o desenvolvimento de um perfilho é importado principalmente de uma folha do perfilho em estádio hierarquicamente mais avançado. Geralmente, as folhas exportam grande proporção de assimilados para os perfilhos em crescimento, ou para um perfilho pequeno, próximo às suas axilas. O meristema intercalar do perfilho, quando se torna ativo, na maioria das vezes, utiliza os assimilados daquelas folhas que exportavam predominantemente para raízes e perfilhos (Ryle, 1970b; Ryle \& Powell, 1972). A independência do perfilho é estabelecida com o seu desenvolvimento. A habilidade para satisfazer sua necessidade de fotoassimilados ocorre quando o perfilho apresenta uma folha completamente expandida (Clifford et al., 1973).

Contudo, a dependência nutricional dos perfilhos tende a se prolongar até a completa expansão da terceira folha, que coincide com a presença da formação do sistema radicular (Klepper et al., 1984). A desfolha da planta pode alterar seu padrão de partição de assimilados. Podemos dividir o desenvolvimento de uma folha em três fases (Figura 5): 


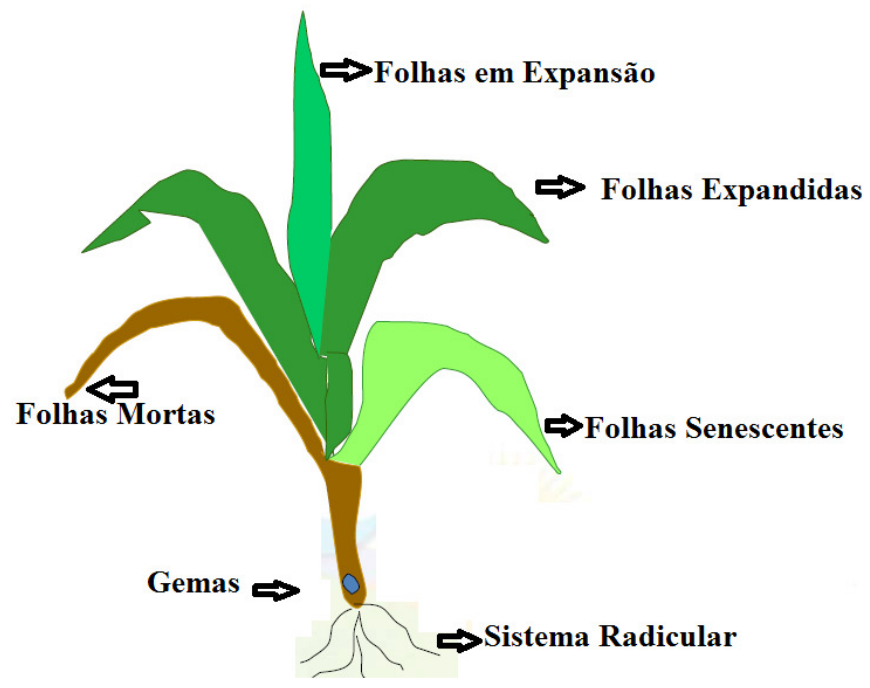

Figura 5 - Perfilho: Unidade básica de produção de uma gramínea

a) fase de expansão foliar, na qual a folha caracteriza-se pela importação líquida (dreno) de compostos orgânicos;

b) fase de folha madura (folha expandida), a capacidade fotossintética é totalmente desenvolvida e ocorre a exportação líquida (fonte) de material orgânico; e

c) fase de senescência, na qual produz uma forte mobilização dos componentes da folha em direção a outras partes da planta, principalmente em termos de conteúdo de proteína. Para atenuar essa perda, tem sido proposto o fornecimento adicional de nitrogênio à planta ou remoção de órgãos dreno. Em geral, a reposição de nutrientes minerais às estruturas em crescimento tem sido apontada como fator de regulação da senescência. O processo de senescência modifica também o movimento estomático induzindo restrição de CO2 e provocando decréscimo na assimilação fotossintética.

Em uma visão mais técnica do manejo, no sentido de máximo aproveitamento dos recursos já produzidos, se o material vegetal não for removido antes de entrar em senescência, é perdido, não sendo transformado em produto animal. 
O conhecimento da partição e da alocação de assimilados pode subsidiar o manejo do cultivo, objetivando sua produtividade, isto é, seu índice de colheita (Beadle, 1993). O manejo da pastagem deve ser orientado no sentido de favorecer a produção e o acúmulo de folhas, em razão não apenas do papel delas na economia da forrageira como também por constituírem a fração mais nutritiva da dieta do ruminante.

A regulação da distribuição de fotoassimilados entre várias vias metabólicas e órgãos na planta é um importante problema, complexo e pobremente entendido. Parte do carbono recentemente fixado ou fotoassimilado em uma folha (fonte) é retido na própria folha e o resto é distribuído para vários tecidos e órgãos não fotossintéticos. A distribuição ocorre em dois níveis: alocação e partição. Alocação refere-se ao destino metabólico do carbono recentemente assimilado na fonte ou liberado para o dreno. O carbono recentemente assimilado pode ser alocado para diversas funções metabólicas na fonte ou no dreno. Na fonte existem 3 principais usos para fotoassimilados: metabolismo na folha e manutenção da biomassa foliar, estocagem a curto prazo, ou exportação para outras partes da planta (Hopkins, 1995).

Em plantas que estocam tanto amido quanto sacarose, existem geralmente dois "pools" de sacarose, um no citoplasma e outro vacuolar (maior, mais lento e serve como primeira fonte de sacarose para exportação à noite). Para estas plantas, somente quando o "pool" vacuolar é diminuído é que o amido estocado no cloroplasto será mobilizado. Aproximadamente metade do carbono recentemente assimilado é alocado para imediata exportação da folha via floema, podendo ser estocado no caminho. Na folha, esse estoque de carboidratos ajuda no tamponamento e suprimento de carbono nos momentos em que as taxas de translocação através do floema estejam reduzidas.

A regulação da alocação é um processo complexo, envolvendo várias vias metabólicas. Alocação dentro de uma folha fonte é, em grande extensão, programado geneticamente, porém existe um forte componente do 
SIMIONI, T.A. et al. Senescência, remoção, translocação de nutrientes e valor nutritivo em gramíneas tropicais. PUBVET, Londrina, V. 8, N. 13, Ed. 262, Art. 1743, Julho, 2014.

desenvolvimento. Folhas jovens, por exemplo, retém grande proporção do seu carbono para o crescimento, porém, em folhas maduras, a proporção de carbono alocado para exportação aumenta.

Com o amadurecimento, a folha alcança a auto-suficiência fotossintética, reduzindo a necessidade e a capacidade de importar assimilados, e o metabolismo da folha se alterada na síntese para a exportação de sacarose.

A distribuição do carbono recentemente assimilado, entre drenos competidores, referida como partição, é determinada pela força do dreno. Em uma planta no estágio vegetativo, os principais drenos são os meristemas e folhas em desenvolvimento no ápice da parte aérea, raízes e tecidos de caules não fotossintéticos.

Com o início do crescimento reprodutivo cria-se drenos adicionais. Se o número de drenos é reduzido, uma correspondente proporção de fotoassimilados é direcionada para cada dreno remanescente. A partição de fotoassimilados entre drenos competidores depende primariamente de 3 fatores: a natureza das conexões vasculares entre fonte e dreno, a proximidade do dreno para a fonte e a força do dreno. A translocação é facilitada por conexões vasculares diretas, onde cada folha é conectada ao sistema vascular principal do caule por menores vasos.

O transporte de carboidratos é realizado sempre no sentido "da fonte para o dreno". Todos os órgãos de uma planta, em algum estádio de desenvolvimento, funcionam como dreno e, apenas alguns órgãos (e.g., folhas) passam de dreno para fonte (Taiz \& Zeiger, 1998). A partição de carboidratos e a importância relativa dos drenos muda ao longo do ciclo da planta, de acordo com a distribuição espacial e função fisiológica dos tecidos em crescimento. O meristema terminal (meristema apical + folhas em expansão + folhas emergentes), os perfilhos, o colmo, a raiz, a inflorescência e a formação de sementes nas plantas em estádio reprodutivo constituem-se nos diversos drenos das gramíneas.

A partição é definida como a distribuição diferencial de fotoassimilados pelos diferentes órgãos da planta e, portanto, determina o modelo de 
SIMIONI, T.A. et al. Senescência, remoção, translocação de nutrientes e valor nutritivo em gramíneas tropicais. PUBVET, Londrina, V. 8, N. 13, Ed. 262, Art. 1743, Julho, 2014.

crescimento da planta, que pode ser balanceado entre parte aérea e sistema radicular. A pressão de turgescência no floema e os mensageiros químicos, como hormônios e nutrientes, são fatores que também controlam a relação fonte/dreno de assimilados (Taiz \& Zeiger, 1998).

Experimentos tem mostrado que fotoassimilados se movem preferencialmente para as folhas dreno acima e na mesma linha da fonte. Estas folhas dreno são diretamente conectadas com a folha fonte, enquanto que folhas dreno em linhas diferentes não estão conectadas diretamente, devendo os fotoassimilados percorrer conecções radiais extensas entre elementos crivados.

Um dos mais significativos fatores na determinação da direção da translocação é a força do dreno. A força do dreno é uma medida da capacidade de um dreno acumular metabólitos (Waring e Patrick, 1975), dada pelo produto do tamanho do dreno pela sua atividade (taxa de absorção). Essa força sofre influência dos fatores ambientais, contudo, existe uma marcada propensão de translocação para o dreno mais estreitamente relacionado.

No estágio vegetativo, os fotoassimilados de uma jovem folha fonte próximo ao topo da planta são translocados preferencialmente para o ápice do caule, enquanto folhas mais velhas não senescentes e próximas da base da planta, preferencialmente suprem as raízes. Folhas intermediárias podem igualmente translocar em ambas as direções, sendo relacionada com a magnitude do gradiente de pressão hidrostática no elemento crivado.

A translocação dos produtos da fotossíntese da fonte para os diversos drenos se faz pelo floema. Embora o modelo de transporte pelo floema represente simplesmente o movimento da fonte para o dreno, o caminho específico entre eles é altamente complexo, pois nem todos os drenos são igualmente supridos por todas as folhas da planta, uma vez que cada fonte supre drenos específicos. O modelo de distribuição dos assimilados é, em grande parte, função da proximidade entre os órgãos, as fontes e os drenos, do estádio de desenvolvimento dos órgãos drenos, das conexões vasculares e da alteração nos caminhos de translocação em que, na ausência de uma 
SIMIONI, T.A. et al. Senescência, remoção, translocação de nutrientes e valor nutritivo em gramíneas tropicais. PUBVET, Londrina, V. 8, N. 13, Ed. 262, Art. 1743, Julho, 2014.

conexão direta entre fonte e dreno (ex. desfolha), as conexões vasculares (anastomoses) constituem um caminho alternativo (Taiz \& Zeiger, 1998).

O estudo da partição de nutrientes na planta forrageira também é importante para tomadas de decisão de manejo da pastagem. Fatores como a transição das folhas de dreno para fonte, padrão de distribuição dos carboidratos das fontes para os drenos, localização dos órgãos de reserva preferenciais, velocidade de translocação dos carboidratos e, consequentemente, da produção de tecidos e da formação de reservas, devem ser considerados na determinação da freqüência, intensidade e época de pastejo (Santos, 1999).

\section{Perfilhamento}

O perfilhamento das gramíneas forrageiras seria a característica mais importante para o aumento da produtividade dessas plantas, mas pode ser influenciada pelo sistema de manejo da pastagem (Ward e Blaser, 1961). Sob pastejo, as plantas sofrem desfolhas sucessivas, cuja freqüência e intensidade dependem principalmente do sistema e da pressão de pastejo.

Apesar de o perfilho produzir o seu próprio sistema radicular, nas fases iniciais após o seu surgimento ele depende da translocação de nutrientes e minerais de outras partes da planta para o seu desenvolvimento, mantendo uma conexão radicular com o perfilho pai (Langer, 1963).

O potencial de perfilhamento de um genótipo, durante o estádio vegetativo, depende de sua velocidade de emissão de folhas, pois cada folha produzida possui gemas potencialmente capazes de originar novos perfilhos, dependendo das condições de meio. A quantidade de perfilhos produzidos e a duração do processo, variam entre espécies e cultivares. O hábito de

crescimento das gramíneas (ereto, rizomatoso e, ou, estolonífero) irá determinar a distribuição e o tipo dos perfilhos dentro do relvado (Vries e Hoogers, 1959).

Cada novo perfilho passa por quatro períodos de crescimento: vegetativo, alongamento, reprodutivo e maturação de sementes. O período de 
SIMIONI, T.A. et al. Senescência, remoção, translocação de nutrientes e valor nutritivo em gramíneas tropicais. PUBVET, Londrina, V. 8, N. 13, Ed. 262, Art. 1743, Julho, 2014.

crescimento vegetativo é caracterizado pelo aparecimento de folhas e perfilhos, e o alongamento é referido como período de transição entre o crescimento vegetativo e o reprodutivo (Moore et al., 1991).

A planta, quando ainda bem jovem, já inicia a emissão de perfilhos, a partir das gemas axilares (Langer, 1963; Ryle, 1964). A densidade de perfilhos é controlada pela taxa de aparecimento de novos perfilhos e pela mortalidade dos perfilhos existentes (Briske, 1991), garantindo perenidade, quando o manejo é satisfatório, às gramíneas forrageiras. Segundo Gomide (1994), o perfilhamento da forrageira é favorecido sob condições de alta intensidade luminosa e temperaturas não elevadas, que favorecem o acúmulo de fotoassimilados nas plantas

A arquitetura do perfilho de uma gramínea é determinada pelo tamanho, número e arranjo espacial dos fitômeros, unidade básica de crescimento das gramíneas, constituído de lâmina, bainha, nó, entre-nó e gema axilar (Briske, 1991).

O potencial de perfilhamento influencia na produção, na qualidade e na persistência das espécies perenes. Dessa forma, maior número de perfilhos significa maior número de folhas e, conseqüentemente, maior número de sítios para o desenvolvimento de perfilhos axilares (Jacques, 1994).

\section{Aspectos nutricionais em gramíneas tropicais}

A manutenção do crescimento de plantas em pastagens depende do suprimento de nutrientes, sendo, portanto, os mais importantes deles o nitrogênio $(N)$, fósforo $(P)$ e o potássio $(K)$. Esses nutrientes podem estar disponíveis para a planta através de vários processos como o seu desprendimento das partículas do solo devido a quebra realizado por agentes físicos ou bioquímicos, mineralização de resíduos de plantas ou animais durante a decomposição e através da adição de fertilizantes no solo (Hodgson, 1990). O nitrogênio assume papel importantíssimo no crescimento e produção das plantas (Langer, 1963), sendo o principal constituinte das proteínas e participante ativo na síntese e composição da matéria orgânica que forma a 
SIMIONI, T.A. et al. Senescência, remoção, translocação de nutrientes e valor nutritivo em gramíneas tropicais. PUBVET, Londrina, V. 8, N. 13, Ed. 262, Art. 1743, Julho, 2014.

estrutura vegetal (Werner, 1986). Para plantas de clima temperado o $\mathrm{N}$ possui uma influencia marcante sobre a taxa de aparecimento de folhas (Korte et al., 1985) e taxa de alongamento de folhas (Lemaire \& Chapman, 1996). Caso o suprimento de $\mathrm{N}$ for adequado e não havendo competição severa por espaço entre as plantas do relvado, a maioria das gemas se desenvolvem em perfilhos. Quando o $\mathrm{N}$ é deficiente, o perfilhamento é inibido e ao aumentar-se o suprimento de $\mathrm{N}$, aumenta-se o numero de perfilhos por planta (Langer, 1963).

De acordo com Cecato et al. (1996), o crescimento e a persistência de gramíneas nos trópicos são freqüentemente limitados pela deficiência de nitrogênio no solo, uma vez que este nutriente acelera a formação e o crescimento de novas folhas e aumenta o vigor de rebrota, melhorando sua recuperação após o corte e resultando em maior produção e capacidade de suporte das pastagens (Figura 6).

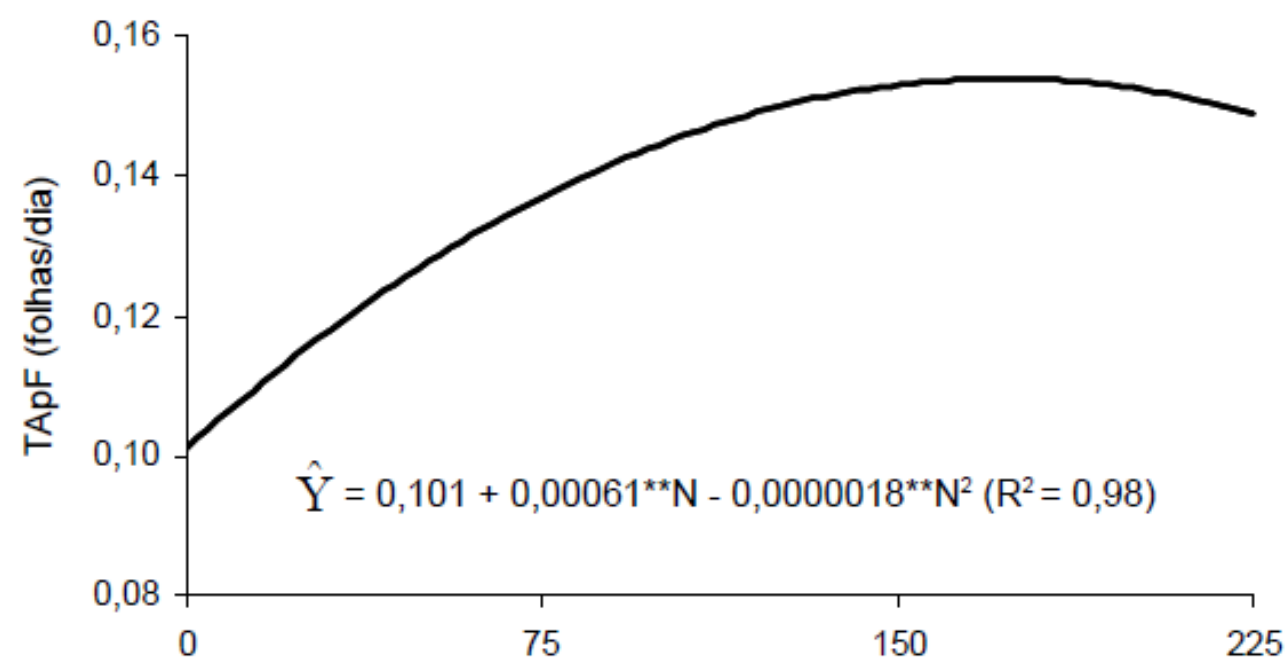

Dose de nitrogênio $\left(\mathrm{mg} / \mathrm{dm}^{3}\right)$

Figura 6 -Taxa de aparecimento foliar - TApF de Brachiaria brizantha e $B$. decumbens adubadas com nitrogênio (Da Silva et al., 2009).

O nitrogênio é o nutriente que apresenta maior limitação para a produtividade das gramíneas. A atmosfera contém aproximadamente $80 \%$ de 
$\mathrm{N}$ na forma de $\mathrm{N} 2$ e vários óxidos de $\mathrm{N}$. Este $\mathrm{N}$ poderá ser disponibilizado para a planta através da fixação biológica ou industrial. O N é o principal constituinte das proteínas. As cadeias de aminoácidos das proteínas são formados pela conversão do $\mathrm{N}$ inorgânico em formas disponíveis para as plantas, que estarão envolvidas na estrutura da clorofila, ATP, DNA e RNA. Na Tabela 1 são apresentadas a quantidade relativa de cada elemento, necessária para o crescimento normal das plantas, e também as formas de íons absorvidas.

Tabela 1 - Concentração média relativa dos elementos essenciais em plantas e as formas absorvidas.

\begin{tabular}{lcc}
\hline Elemento & umol/g matéria seca & Forma absorvida do íon \\
\hline Nitrogênio & 1,000 & $\mathrm{NH}^{+}, \mathrm{NO}^{-}$ \\
Potássio & 250 & $\mathrm{~K}^{+}$ \\
Cálcio & 125 & $\mathrm{Ca}^{2+}$ \\
Magnésio & 80 & $\mathrm{Mg}^{2+}$ \\
Fósforo & 60 & $\mathrm{H}_{2} \mathrm{PO}^{4-}, \mathrm{HPO}_{4}{ }^{2-}, \mathrm{PO}_{4}{ }^{3-}$ \\
Enxofre & 30 & $\mathrm{SO}_{4}{ }^{2-}$ \\
Cloro & 3.0 & $\mathrm{Cl}^{-}$ \\
Boro & 2.0 & $\mathrm{H}_{3} \mathrm{BO}_{3}$ \\
Ferro & 2.0 & $\mathrm{Fe}^{2+}$ \\
Manganês & 1.0 & $\mathrm{Mn}^{2+}$ \\
Zinco & 0.3 & $\mathrm{Zn}^{2+}, \mathrm{ZnOH}^{+}, \mathrm{ZncL}^{+}$ \\
Cobre & 0.10 & $\mathrm{Cu}^{+}$ \\
Molibdênio & 0.001 & $\mathrm{MoO}_{4}{ }^{2-}$
\end{tabular}

Fonte: Joost, 1996.

A forma do $\mathrm{N}$ recebida pelas gramíneas é determinada em grande parte pelo $\mathrm{pH}$ do solo e temperatura. $\mathrm{O}$ nitrato é a forma predominante de $\mathrm{N}$ recebida pela maioria das culturas desde que $0 \mathrm{NH}^{+}$de resíduos de 
fertilizantes orgânicos e inorgânicos do solo seja rapidamente oxidado pelos microrganismos do solo.

O fósforo é freqüentemente o segundo nutriente mineral mais limitante para a produção das plantas. Os fertilizantes fosfatados são formados por reações em minas de fosfato de rocha com ácidos. A forma iônica do fosfato encontrado é determinado pelo $\mathrm{pH}$ do solo. Nos solos agrícolas, devido aos níveis de $\mathrm{pH}$ comumente encontrados, as formas predominantes são $\mathrm{HPO}_{4}{ }^{2-} \mathrm{e}$ $\mathrm{H} 2 \mathrm{PO}_{4}{ }^{2-}$.

A principal função do $P$ nas plantas e animais é o seu envolvimento na estocagem de energia através da alta energia das ligações do $P$, encontradas no ATP.

\section{Eficiência nutricional para produção das forrageiras}

Nas últimas décadas, especialmente nos anos 90, a produção agrícola tem aumentado; entretanto, a aplicação de fertilizantes diminuiu, o que poderia ser explicado pela maior eficiência de uso de nutrientes pelas culturas (Epstein \& Bloom, 2006).

Desse modo, como a absorção, o transporte e a redistribuição de nutrientes apresentam controle genético, existe a possibilidade de melhorare ou selecionar cultivares mais eficientes quanto ao uso de nutrientes (Gabelman \& Gerloff, 1983).

Em uma planta colhida fresca, dependendo da espécie, pode-se observar que a maior proporção de sua massa, de 70 até $95 \%$, é constituída por água (H2O). Observa-se, de maneira geral, o predomínio de $\mathrm{C}, \mathrm{H}$ e O, compondo $92 \%$ da matéria seca das plantas (Tabela 2 ).

A suscetibilidade à degradação ruminal da porção fibrosa varia entre espécies e com a idade ou nível de maturação da forrageira. À medida que se avança no desenvolvimento vegetal rumo ao estágio de maturação, ocorre drástica diminuição do teor protéico e aumento do teor de fibra, associado ao aumento no teor de lignina. A lignina forma uma barreira que impede a aderência microbiana e a hidrólise enzimática da celulose e hemicelulose, 
SIMIONI, T.A. et al. Senescência, remoção, translocação de nutrientes e valor nutritivo em gramíneas tropicais. PUBVET, Londrina, V. 8, N. 13, Ed. 262, Art. 1743, Julho, 2014.

indisponibilizando os carboidratos estruturais potencialmente degradáveis, diminuindo a digestibilidade da fibra e a qualidade e o aproveitamento da forragem (Rodrigues et al., 2004).

Tabela 2 - Composição relativa dos nutrientes presentes na matéria seca das plantas.

\begin{tabular}{|c|c|c|c|}
\hline Classificação & Nutriente (forma elementar) ${ }^{1}$ & Participação & Total \\
\hline
\end{tabular}

\begin{tabular}{lccc}
\hline Macronutrientes & C & 42 & \\
orgânicos & O & 44 & \\
& H & 6 & 92 \\
& N & & \\
Macronutrientes & P & 2 & \\
& K & 0,4 & \\
& Ca & 2,5 & \\
& Mg & 1,3 & \\
& $\mathrm{~S}$ & 0,4 & 7
\end{tabular}

Micronutrientes

$\mathrm{Cl}, \mathrm{Fe}, \mathrm{Mn}, \mathrm{Zn}, \mathrm{B}, \mathrm{Cu}, \mathrm{Mo}$

1

Total geral

100

${ }^{1}$ Nem sempre a forma elementar dos nutrientes é a forma química que as plantas absorvem.

A ordem-padrão, decrescente de extração das culturas em geral, é a seguinte:

Macronutrientes: $\mathrm{N}>\mathrm{K}>\mathrm{Ca}>\mathrm{Mg}>\mathrm{PS}$

Micronutrientes: $\mathrm{Cl}>\mathrm{Fe}>\mathrm{Mn}>\mathrm{Zn}>\mathrm{B}>\mathrm{Cu}>\mathrm{Mo}$

Mas, considerando as culturas apresentadas na Tabela 3, nota-se que houve alteração para essa ordem de extração total de nutrientes. Nos macronutrientes, observa-se, em capim-braquiária e capim-pé-de-galinha, 
SIMIONI, T.A. et al. Senescência, remoção, translocação de nutrientes e valor nutritivo em gramíneas tropicais. PUBVET, Londrina, V. 8, N. 13, Ed. 262, Art. 1743, Julho, 2014.

maior exigência para o $\mathrm{K}$ em relação ao $\mathrm{N}$. Nota-se que a extração de micronutrientes (exceto o $\mathrm{Fe}$ ) pelos capins é inferior a $1 \mathrm{~kg} \mathrm{ha}^{-1}$ (Tabela 3), implicando que as doses indicadas para atender à exigência nutricional é igual ou inferior a $2 \mathrm{~kg} \mathrm{ha}^{-1}$ (Vilela et al., 2007). As forrageiras com alta produção de biomassa, como colonião (23 t ha-1), apresentam alta extração de nutrientes: $\mathrm{K}=363 ; \mathrm{N}=288 ; \mathrm{Ca}=149 ; \mathrm{Mg}=99$ e $\mathrm{P}=44 \mathrm{~kg}$ ha-1 (Sanchez, citado por Macedo, 2004).

Tabela 3 - Extração total (parte aérea) de algumas forrageiras

\begin{tabular}{|c|c|c|c|c|}
\hline & & \multicolumn{3}{|c|}{ Forrageiras } \\
\hline & & - & $13,5 \mathrm{t} \mathrm{ha}^{-1}$ & 6,4 t ha $^{-1}$ \\
\hline & & Capim braquiária ${ }^{1}$ & Capim-moa ${ }^{2}$ & Capim pé de galinha ${ }^{3}$ \\
\hline \multirow{7}{*}{ 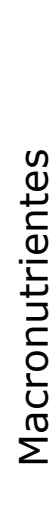 } & & & $\mathrm{Kg} \mathrm{ha}^{-1}$ & \\
\hline & $\mathrm{N}$ & 59,4 & 130 & 116,7 \\
\hline & $\mathrm{P}$ & 14,6 & 28 & 12,6 \\
\hline & $\mathrm{K}$ & 145,9 & 91 & 131,9 \\
\hline & $\mathrm{Ca}$ & 14 & 37 & 47,5 \\
\hline & $\mathrm{Mg}$ & 14,5 & 35 & 18,6 \\
\hline & $\mathrm{S}$ & - & 6 & 16,4 \\
\hline \multirow{7}{*}{ 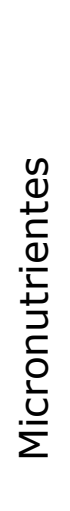 } & & & $\mathrm{g} \mathrm{ha}^{-1}$ & \\
\hline & $B$ & - & - & - \\
\hline & $\mathrm{Cu}$ & 21,6 & 53,5 & 106,8 \\
\hline & $\mathrm{Fe}$ & 4430 & 5653 & 633,2 \\
\hline & Mn & 918 & 718 & 596,3 \\
\hline & Mo & - & - & - \\
\hline & $\mathrm{Zn}$ & 194,5 & 490,2 & 231,7 \\
\hline
\end{tabular}

${ }^{1}$ B.brizantha, cultivada em solo sob o manejo pelo sistema "barreirão" (Magalhães et al., 2002); ${ }^{2}$ Setaria incana referente à parte aérea com grãos, aos 69 dias após semeadura (Nakazu et al., 2006); ${ }^{3}$ Eleusine coracana L. Gaertn., referente à parte aérea, na época do florescimento (Francisco, 2002). 
Lavezzo et al. (1980), ao trabalharem com forrageiras tropicais cortadas em diferentes idades, observaram decréscimo na digestibilidade in vitro da matéria seca com o envelhecimento das plantas.

Os diferentes tipos de tecidos vegetais influenciam na digestibilidade da forragem. Moore e Miller (1988) observaram que a diferença na composição da parede celular das forragens, explica a menor digestibilidade do caule em relação à das folhas. Portanto, com o avanço da idade, há redução na proporção de folhas e na digestibilidade da matéria seca das plantas, com queda no valor nutritivo. Este fato da idade na composição química das forragens é relatado na Tabela 4.

Tabela 4 - Princípios nutritivos de algumas gramíneas tropicais.

\begin{tabular}{ccccccccc}
\hline Alimento & Estádio de & \multicolumn{6}{c}{ Composição Química (\% da Matéria seca) } \\
Forrageira & Crescimento & PB & NDT & FB & FDN & FDA & Ca & P \\
\hline \multirow{3}{*}{$\begin{array}{c}\text { Capim- } \\
\text { elefante }\end{array}$} & Com 22 dias & 13,5 & 56,5 & 27 & 54 & 36 & 0,3 & 0,24 \\
& Com 45 dias & 8,2 & 50,5 & 32 & 62 & 43 & 0,35 & 0,28 \\
& Com dias & 7 & 48,1 & 33,7 & 66 & 47 & 0,5 & 0,16 \\
Capim- & Com 20 dias & 6,5 & 47,2 & 36 & -- & -- & 0,18 & 0,1 \\
colonião & Com 40 dias & 8,5 & 55 & 36.6 & 65 & 45 & 0,42 & 0,22 \\
& Com 60 dias & 5,5 & 47 & 39 & 72 & 51 & 0,28 & 0,17 \\
\hline Brachiaria & Vegetativo & 11,7 & 59,3 & 20,8 & -- & -- & 0,49 & 0,2 \\
brizanta & Floração & & & & & & & \\
& completa & 5,3 & 50,7 & 30 & 71 & 50 & 0,2 & 0,1 \\
\hline
\end{tabular}

Fonte: adaptado de ANDRIGUETTO et al. (1996) e NRC (1996).

Normalmente, a exigência nutricional de uma determinada forrageira poderá ser afetada pelo sistema de produção adotado, ou seja, produção de forragem ou de grãos/sementes. Nesse sentido, os requerimentos de fertilidade do solo para produção de sementes de determinada cultivar são 
SIMIONI, T.A. et al. Senescência, remoção, translocação de nutrientes e valor nutritivo em gramíneas tropicais. PUBVET, Londrina, V. 8, N. 13, Ed. 262, Art. 1743, Julho, 2014.

superiores àqueles necessários para essa mesma cultivar quando utilizada como pastagem (Souza, 2001).

Por outro lado, na prática, as culturas que exportam com a colheita grande parte dos nutrientes absorvidos, ou aquelas cujo produto colhido é toda a parte aérea (cana-de-açúcar, milho, silagem, pastagem) deixam muito pouco restos de cultura e, assim, merecem mais atenção em termos de necessidade de reposição desses nutrientes, por meios de adubação de manuntenção. Isso é importante, porque na gestão da ótima adubação é preciso considerar um sistema de produção, envolvendo várias culturas com exigências nutricionais e taxas de exportação distintas.

Entretanto, os restos culturais deixados na superfície do solo podem ser reciclados e aproveitados pelas plantas, atingindo $60 \%$ a $70 \%$ para o $\mathrm{N} ; 100 \%$ para o K (Spain \& Salinas, 1985) e 77\% para o P (Jones \& Woodmanse, 1979). Diante da reciclagem, espera-se que os nutrientes satisfaçam parte da necessidade da forrageira e, portanto, a exigência nutricional da pastagem na fase de manutenção seria inferior à fase de estabelecimento. Além disso, a forrageira, na fase de implantação, apresentaria maior produção de biomassa (cerca de 30\%), comparada aos demais ciclos de crescimento, pois a ausência de estresse fisiológico da planta, induzido pelo pastejo, elevaria a exigência nutricional no primeiro ciclo de crescimento.

\section{VALOR NUTRITIVO DE GRAMÍNEAS TROPICAIS}

\section{Crescimento}

O número de folhas vivas por perfilho, constante para cada espécie, constitui critério objetivo na definição do intervalo de cortes das plantas forrageiras (Fulkerson e Slack, 1995).

A produção de folhas num perfilho é um processo contínuo, existindo quatro tipos de folhas que apresentam características próprias durante o seu ciclo de vida. As folhas em expansão que estão envolvidas pelo pseudocolmo (crescimento); folhas emergentes apresentando as lâminas visíveis; folhas 
SIMIONI, T.A. et al. Senescência, remoção, translocação de nutrientes e valor nutritivo em gramíneas tropicais. PUBVET, Londrina, V. 8, N. 13, Ed. 262, Art. 1743, Julho, 2014.

completamente expandida em uma fase de máximo desempenho fotossintético (maturidade) e as folhas senescentes (Gomide, 1997b). Parte do período de crescimento pode acontecer no interior das bainhas de outras folhas até que possa ser visível.

Corsi et al. (1994), trabalhando com três espécies do gênero Brachiaria, encontraram número médio de folhas verdes que variou de 5 a 7 folhas, definindo um período de descanso próximo de 30 a 35 dias para as espécies estudadas.

A produtividade das gramíneas forrageiras decorre da contínua emissão de folhas e perfilhos, processo importante para a restauração da área foliar após corte ou pastejo e que garante a perenidade à forrageira.

O ciclo de vida de folhas sucessivas em um perfilho está intimamente relacionado, uma vez que o aparecimento de uma nova folha, a cessação do crescimento da folha anterior e a senescência de uma folha madura acontecem mais ou menos ao mesmo tempo. Isto define um número mais ou menos constante de folhas em um perfilho (Hodgson, 1990) (Tabela 5).

A taxa de crescimento em certo ponto pode ser limitada tanto pelo suprimento de assimilados fotossintéticos (Hodgson et al., 1981; Davies, 1988), pelas reservas das plantas, ou pelo número, tamanho e atividade dos pontos de crescimento (Hodgson et al., 1981; Davies, 1988; Hodgson, 1990).

À medida que avança a maturidade da planta, aumenta a proporção dos tecidos condutores e mecânicos nas folhas, provocando redução na área foliar específica (PINTO, 1993). Cultivares de uma mesma espécie podem apresentar comportamentos diferenciados com relação aos índices de crescimento (GOMIDE, 1996).

A eficiência fotossintética do tecido foliar pode ser afetada pela densidade de população de perfilhos e pela distribuição de folhas de diferentes idades no dossel, por isso a produção de assimilados não é uma simples função da área foliar (Hodgson et al., 1981). 
SIMIONI, T.A. et al. Senescência, remoção, translocação de nutrientes e valor nutritivo em gramíneas tropicais. PUBVET, Londrina, V. 8, N. 13, Ed. 262, Art. 1743, Julho, 2014.

Tabela 5 -Número médio de folhas vivas por perfilho, em algumas gramíneas forrageiras tropicais.

\begin{tabular}{lll}
\hline Planta Forrageira & Valor & Referência \\
\hline Andropogon gayanus & 5 & Pinto et al. (1993) \\
$\begin{array}{l}\text { Brachiaria brizantha } \\
\text { Brachiaria decumbens }\end{array}$ & 5 a 7 & Corsi et al. (1994) \\
$\begin{array}{l}\text { Brachiaria decumbens } \\
\text { Cynodon Spp. (no máximo obtido }\end{array}$ & Corsi et al. (1994) \\
aos 28 dias) & 5 & Gomide et al. (1994) \\
Cynodon spp. cv. Coastcross & 10,7 & Oliveira et al. (1998) \\
Cynodon spp. cv. Florakirk & 5,6 & Pinto (2000) \\
Cynodon spp. cv. Tifton-85 & 5,4 & Pinto (2000) \\
Panicum maximum cv. Colonião & 4,6 & Pinto (2000) \\
Panicum maximum cv. Guiné & 4,6 & Pinto et al. (1993) \\
Panicum maximum cv. Vencedor & 6 & Gomide \& Gomide (1997) \\
Panicum maximum cv. Mombaça & 4 & Gomide \& Gomide (1997) \\
Panicum maximum cv. Tanzânia & 3,5 & Gomide \& Gomide (1997) \\
Panicum maximum cv. Tanzânia & 4,8 & Rosseto (2000) \\
Penisetum purpurreum cv. Mott & 5,4 a 6,8 & Almeida et al. (1997) \\
Penisetum purpurreum cv .Guaçu & 7,1 & Rosseto (2000) \\
Setaria anceps cv. Kazungula & 6,6 & Pinto et al. (1994)
\end{tabular}

Adaptado de Pedreira et al. (2008)

\section{Relação Folha/Caule}

Deinum et al. 1985, citados por Zimmer et al. (1988), observaram que a percentagem de folhas, em B. ruziziensis está relacionada com o peso e idade dos perfilhos, além da influência da temperatura, intensidade luminosa e da interação entre estes fatores. Perfilhos mais velhos e desenvolvidos possuem menor percentagem de folhas, ou seja, a relação $F / C$ diminui à medida que a rebrotação envelhece. Perfilhos jovens apresentam cerca de $8 \%$ mais folhas do 
SIMIONI, T.A. et al. Senescência, remoção, translocação de nutrientes e valor nutritivo em gramíneas tropicais. PUBVET, Londrina, V. 8, N. 13, Ed. 262, Art. 1743, Julho, 2014.

que os perfilhos velhos. A percentagem de folhas, segundo estes mesmos autores, varia de $73 \%$ para $47 \%$ quando a rebrotação passava de 2 para 5 semanas de idade, bem como há uma redução no teor de PB e aumento no teor de fibra bruta.

O efeito do N, no aumento da relação lâmina/colmo, é importante, pois o aumento da proporção da lâmina foliar diminui o tempo de pastejo do animal para satisfazer suas exigências. E ainda, avaliações agronômicas têm demonstrado que a qualidade do capim aumenta com o uso de cultivares com maior relação folha/caule (Boval et al., 2002).

Iniciado o processo de alongamento do colmo, o meristema apical é progressivamente "empurrado" para cima, expondo-se à destruição por corte ou pastejo. A elevação do meristema apical, além de colocá-lo em posição de alta vulnerabilidade (Jewiss, 1966), provoca redução brusca na relação folha/colmo, o que contribui para diminuição no valor nutritivo da forrageira (Andrade \& Gomide, 1971). O alongamento do colmo constitui-se em forte dreno de fotoassimilados e nutrientes das folhas basilares (Dale, 1982).

\section{Qualidade de Gramíneas Tropicais}

Qualidade da forragem é definida como a associação entre valor nutritivo e consumo da mesma pelo animal em pastejo. O valor nutritivo, por sua vez, é dado pela composição química e digestibilidade (Reis \& Rodrigues, 1993). Desse modo, a qualidade da forragem é influenciada tanto por fatores nutricionais (valor nutritivo), quanto pelos não nutricionais (quantidade de forragem ofertada ao animal) (Poppi et al., 1987).

É sabido, que à medida que aumenta a quantidade de forragem disponível, há tendência de diminuição de qualidade (Figura 7). O que se deve buscar é o ponto adequado para obter-se o máximo rendimento, com a melhor qualidade possível, o que corresponderia a estar empregando uma pressão de pastejo compatível com a capacidade de suporte da pastagem (Evangelista, 2000). 


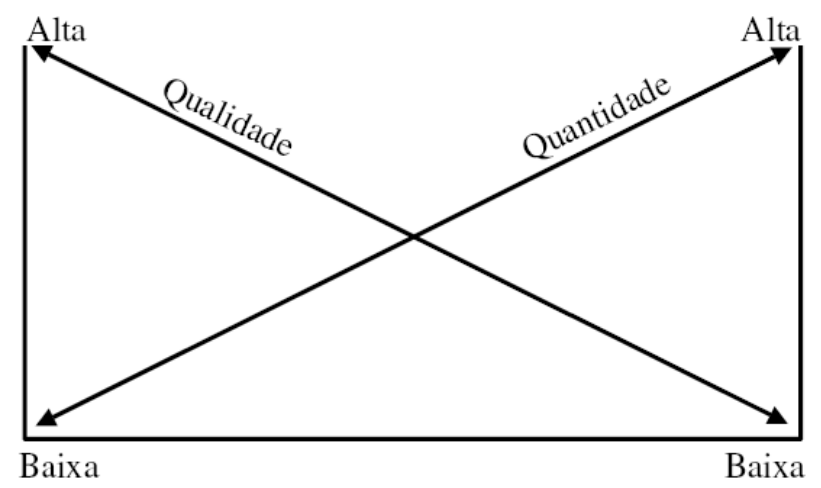

Figura 7 - Relação entre quantidade e qualidade de forragem (Gardner e Alvim, 1985).

O manejo para quantidade, baseado na manutenção do meristema apical e índice de área foliar, permite rebrota vigorosa e rápida. Entretanto, como o crescimento do colmo não foi interrompido, observa-se que, mesmo a intervalos freqüentes de pastejo, ocorre acúmulo de material residual, caracterizado pela presença de colmos lignificados e partes mortas da planta, capaz de prejudicar o consumo e utilização da forragem.

O manejo para qualidade envolve um conjunto de práticas/atividades destinadas a alterar a morfologia ou retardar a maturidade da planta, dentro da meta de aumentar o nível de nutrientes digestíveis na dieta para bovinos e garantir desempenho compatível com a bovinocultura de ciclo curto.

Períodos longos de crescimento, apesar de resultarem em maiores acúmulos de forragem, contribuem para um menor valor nutritivo, tanto por modificações na estrutura do dossel, através do aumento nas frações haste e material senescido e decréscimo proporcional na produção de folhas (Reis \& Rodrigues, 1993; Carnevalli, 2003), quanto por alterações em nível celular, representado pelo aumento dos teores de carboidratos estruturais e lignina (componentes da parede celular) e reduções no conteúdo celular (Reis \& Rodrigues, 1993; Van Soest, 1994).

Foi sumarizado na Tabela 6 trabalhos avaliando a composição químico bromatológica e digestibilidade da forragem de pastagens diferidas no momento de sua utilização. Os trabalhos apresentados foram avaliados em 
SIMIONI, T.A. et al. Senescência, remoção, translocação de nutrientes e valor nutritivo em gramíneas tropicais. PUBVET, Londrina, V. 8, N. 13, Ed. 262, Art. 1743, Julho, 2014.

cortes, sendo que os tratamentos testaram diferentes épocas de vedação e utilização da pastagem. Dessa forma os valores mínimo e máximo representam o intervalo gerado pelos diferentes períodos de crescimento da planta forrageira em cada experimento.

Considerando os estádios de desenvolvimento de uma planta como um todo, observa-se que à medida que o desenvolvimento progride em direção a floração o valor nutritivo diminui, apesar do elevado rendimento de biomassa. Tomando como exemplo uma gramínea observa-se que a medida que o desenvolvimento progride, ocorre um aumento nos teores de fibra.

Por outro lado, os teores de proteína e carboidratos não estruturais (açúcar e amido) reduzem sensivelmente na medida em que a planta se aproxima do estádio de floração, com uma maior participação dos colmos em relação às folhas na composição total da biomassa.

Para elevar a produção animal, o estádio de desenvolvimento da forrageira assume grande importância, uma vez que a alta produção animal é diretamente associada ao consumo de matéria seca com alta percentagem de folhas, de proteínas e de digestibilidade.

Gramíneas quando no estádio vegetativo, permitem aumento na quantidade de forragem apreendida pelo animal (bovino) e consequentemente um aumento no consumo de matéria seca digestível. Pois o consumo maior de folhas em relação ao colmo provoca a mais rápida digestão e consequentemente, menor tempo de passagem da forragem, propiciando oportunidade para maior consumo.

Além das características qualitativas, a disponibilidade de forragem aos animais, dependente do manejo, também deve atender aspectos da produção de forragem e animal e, para tal, o pastejo deve ser controlado para permitir que as plantas maximizem o aproveitamento dos recursos do ambiente no tempo e no espaço e para permitir a maximização do consumo de energia pelo animal. 
Tabela 6 - Composição químico bromatológica e digestibilidade máximo e mínima em pastagens diferidas, no momento da utilização.

Espécie

$$
\text { Valor Valor Crescimento }
$$

Minimo Máximo Min. Máx.

Fonte

\begin{tabular}{|c|c|c|c|c|c|}
\hline \multirow[b]{2}{*}{$\begin{array}{c}\text { Brachiaria e } \\
\text { Cynodon }\end{array}$} & \multicolumn{2}{|c|}{ PB (\%) } & \multicolumn{2}{|c|}{ Dias } & \multirow[b]{2}{*}{$\begin{array}{l}\text { Euclides et a. } \\
\qquad(1990)^{1}\end{array}$} \\
\hline & 5,5 & 11,1 & 30 & 240 & \\
\hline $\begin{array}{l}\text { A. gayanus cv. } \\
\text { Planaltina }\end{array}$ & 5,1 & 8,7 & 61 & 214 & $\begin{array}{c}\text { Costa \& Oliveira } \\
(1992)^{1}\end{array}$ \\
\hline Capim-marandu & 6,1 & 9,7 & 63 & 214 & Costa et al. $(1993)^{1}$ \\
\hline B. decumbens & 2,5 & 5,9 & 28 & 308 & Pizarro et al. (1998) \\
\hline B. brizantha & 4,8 & 6,7 & 60 & 210 & Leite et al. (1998) \\
\hline Capim-marandu & 4 & 6 & 81 & 196 & Bueno et al. (2000) \\
\hline Capim-marandu & 2,6 & 3,1 & 48 & 224 & Gomes (2003) \\
\hline \multicolumn{6}{|c|}{ DIVMS (\%) } \\
\hline $\begin{array}{c}\text { Brachiaria e } \\
\text { Cynodon }\end{array}$ & 50 & 62,4 & 30 & 240 & $\begin{array}{l}\text { Euclides et a. } \\
\qquad(1990)^{1}\end{array}$ \\
\hline Capim-marandu & 47,1 & 63,4 & 63 & 214 & Costa et al. $(1993)^{1}$ \\
\hline B. decumbens & 49 & 62 & 28 & 308 & Pizarro et al. (1998) \\
\hline B. brizantha & 53,5 & 60,7 & 60 & 210 & Leite et al. (1998) \\
\hline Capim-marandu & 44,5 & 55,4 & 81 & 196 & Bueno et al. (2000) \\
\hline Capim-marandu & 36,01 & 53,36 & 48 & 224 & Gomes (2003) \\
\hline \multicolumn{6}{|c|}{ FDA (\%) } \\
\hline B. brizantha & 61,3 & 69,2 & 60 & 210 & Leite et al. (1998) \\
\hline Capim-marandu & 66,5 & 71,3 & 81 & 196 & Bueno et al. (2000) \\
\hline Capim-marandu & 71,1 & 79,9 & 48 & 224 & Gomes (2003) \\
\hline \multicolumn{6}{|c|}{ Lignina (\%) } \\
\hline Capim-marandu & 2 & 4,9 & 81 & 196 & Bueno et al. (2000) \\
\hline
\end{tabular}

${ }^{1}$ Variáveis analisadas na fração MSV (Adaptado de Carvalho et al., 2006) 


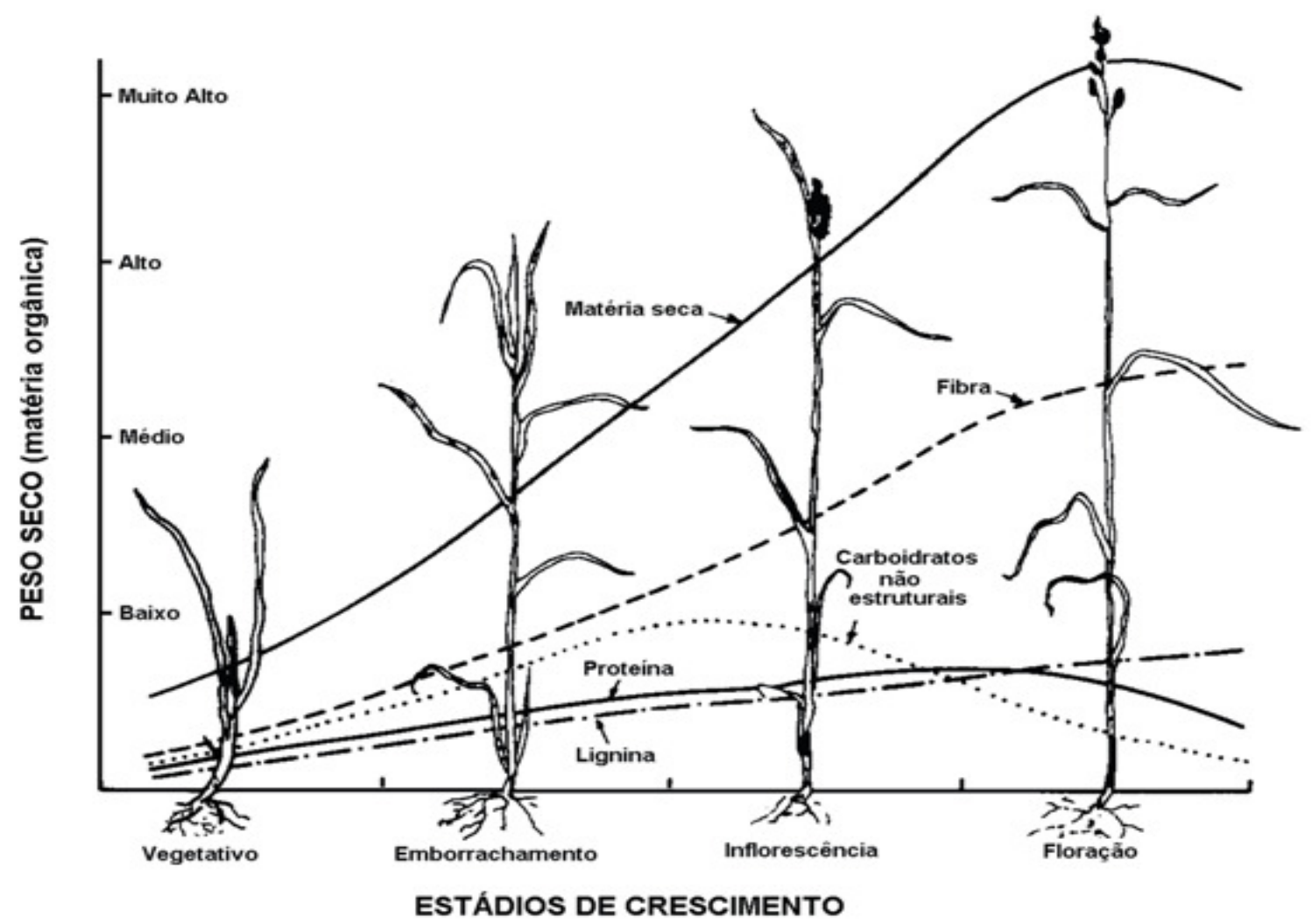

Figura 8 - Dinâmica do crescimento de gramíneas e leguminosas do estádio vegetativo ao início da floração e seus respectivos teores (\%) de proteína, minerais, fibras e lignina, com a conseqüente redução na proporção de folhas e aumento na proporção de caules (Blaser e Novaes, 1990).

A eficiência de utilização do pasto depende de sua estrutura, já que maior proporção de colmos e material senescente altera o comportamento ingestivo dos ruminantes limitando o consumo, e também da densidade de lotação utilizada.

As forrageiras não crescem uniformemente ao longo do ano. Além de variações de temperatura e fotoperíodo, a estacionalidade das chuvas, característica das regiões tropicais, não permite uma produção uniforme de forragem durante o ano, assim podemos mostrar a variação dos teores de PB e de DIVMO (Tabela 7) de algumas gramíneas tropicais nos períodos de águas e seca. As taxas de crescimento (quilo de matéria seca/hectare/dia) são maiores nos meses de verão, intermediárias nos meses de primavera e outono 
SIMIONI, T.A. et al. Senescência, remoção, translocação de nutrientes e valor nutritivo em gramíneas tropicais. PUBVET, Londrina, V. 8, N. 13, Ed. 262, Art. 1743, Julho, 2014.

e muito baixas nos meses de inverno. Além dessas variações nas taxas de crescimento da planta, existem alterações nas características morfológicas da pastagem. Durante a estação de crescimento há acúmulo de material morto associado à senescência natural da planta forrageira que é acelerada por déficit hídrico ou por geadas (Euclides, 2000).

Tabela 7 - Médias dos conteúdos de proteína bruta (PB) e digestibilidade in vitro da matéria orgânica (DIVMO) em amostras simulando o pastejo animal, nos períodos das águas e da seca.

\begin{tabular}{lllll}
\hline & \multicolumn{3}{c}{ PB (\%) } & \multicolumn{2}{c}{ DIVMO (\%) } \\
Águas & Seca & Água & Seca \\
\cline { 2 - 5 } Colonição & 12,4 & 10,3 & 59,6 & 52 \\
Tobiatã & 10,8 & 8,4 & 55,9 & 49,3 \\
Tanzânia & 10,6 & 8 & 57,7 & 53,3 \\
B. decumbens & 7,7 & 5,6 & 58,7 & 51,9 \\
Marandu & 8,1 & 5,8 & 58,8 & 52,1 \\
\hline
\end{tabular}

Fonte: Euclides et al. (1996)

O manejo de pastagens visa proporcionar rebrota vigorosa, favorecer a perenidade do pasto, obter elevada produção de matéria seca de boa qualidade, sincronizar disponibilidade e necessidade de forragem, e atingir elevado nível de aproveitamento da forragem produzida, reduzindo as perdas por senescência e aumentando a eficiência de colheita. Além disso, nos últimos anos vem aumentando a preocupação com a sustentabilidade do sistema e do meio ambiente.

A importância relativa de cada um destes objetivos vai depender do sistema de produção e do contexto em que este está inserido (Santos et al., 2004). Em comunidades de plantas pastejadas há equilíbrio entre crescimento, senescência e consumo pelos animais. Assim, se em dado momento o consumo for superior ao crescimento, modificações deverão ocorrer para que um novo equilíbrio se estabeleça. Normalmente, há redução na quantidade de forragem produzida, alterações morfológicas na planta e na densidade 
SIMIONI, T.A. et al. Senescência, remoção, translocação de nutrientes e valor nutritivo em gramíneas tropicais. PUBVET, Londrina, V. 8, N. 13, Ed. 262, Art. 1743, Julho, 2014.

populacional, resultando em redução na quantidade removida pelo animal. Em situação contrária, o excesso de crescimento frente às quantidades removidas pelos animais fará com que ocorram perdas de forragem pelo processo de senescência, em que o acúmulo líquido de forragem tenderá a zero (Parsons et al., 1988).

A relação entre a quantidade consumida pelo animal e a quantidade produzida pelas plantas é definida como eficiência de utilização da pastagem. Assim, práticas de manejo que resultem na remoção da forragem pelo animal no momento em que a taxa média de acúmulo de forragem verde é máxima e, portanto, a senescência é mínima, maximizarão a eficiência de utilização da pastagem (Lemaire e Chapman, 1996).

\section{Reservas Orgânicas x IAF}

Preconiza-se que as pastagens devam ser manejadas de forma a permitir a pronta recuperação das plantas pastejadas. Embora reconhecendo que a manutenção de um IAF ótimo sob condições de pastejo seja praticamente impossível, é razoável admitir que o crescimento da planta será conduzido com a manutenção de um IAF baixo, devido a inadequada interceptação de luz pelas plantas. Por outro lado, o acúmulo de matéria seca também será reduzido com a manutenção de valores elevados de IAF em decorrência do aumento na atividade respiratória e da acelerada senescência de folhas (Hodgson, 1990).

Os responsáveis pela mantença da sobrevivência dos tecidos remanescentes e da respiração celular, segundo alguns autores citados por Carvalho et al. (2001), logo após o corte ou pastejo, são as reservas orgânicas e o IAF remanescente. A área foliar remanescente após a desfolhação assume importância para aumentar o vigor da rebrotação devido à imediata produção de carboidratos pela fotossíntese, proporcionando à planta menor tempo de dependência sobre o nível de carboidratos de reserva para sua recuperação. Para gramíneas tropicais o efeito das reservas é mais importante quando os 
SIMIONI, T.A. et al. Senescência, remoção, translocação de nutrientes e valor nutritivo em gramíneas tropicais. PUBVET, Londrina, V. 8, N. 13, Ed. 262, Art. 1743, Julho, 2014.

cortes são mais drásticos, com a conseqüente redução da área foliar remanescente (Corsi \& Nascimento Jr, 1994).

Em geral, após a desfolhação, os assimilados recém-sintetizados nas folhas residuais, bem como as reservas orgânicas, contribuem para a reconstituição da área foliar, priorizando os meristemas terminais (Schnyder \& De Visser, 1999). De modo geral, logo que a planta inicia a rebrotação e há aumento do IAF, as reservas não atuam mais como energia de rebrotação e passam novamente a ser acumuladas.

O crescimento das gramíneas é determinado a partir de uma relação de balanço liquido entre o aumento em área foliar, descontando-se a senescência e o tecido aéreo destacado, que estariam disponíveis para uso animal (Soria, 2002).

Cabe ressaltar que valores baixos de IAF indicam um relvado pouco denso enquanto que, altos, indicam um relvado denso. Para cada espécie forrageira e condições de crescimento existe um IAF que promove um nível ótimo de crescimento, pois este possibilita uma máxima interceptação da luz e uma melhor taxa de fotossíntese.

\section{SENESCÊNCIA}

As folhas de gramíneas são órgãos de crescimento de vida útil limitada, uma vez que, quando alcançam o seu tamanho final, elas permanecem no perfilho por um certo período, e depois morrem. O processo de senescência se inicia no ápice da folha, que é a parte mais velha, e se estende para a base (Langer, 1963). O progressivo amarelecimento e eventualmente escurecimento (cor marrom) e a desidratação são os primeiros sinais visíveis de senescência. Nos estádios iniciais desse processo, parte dos constituintes celulares é mobilizada e redistribuída, mas a maioria é usada na própria respiração do órgão senescente (Hodgson, 1990).

O conhecimento da taxa de senescência foliar de um genótipo, além de suas características morfogênicas, pode indicar mudanças no manejo de 
SIMIONI, T.A. et al. Senescência, remoção, translocação de nutrientes e valor nutritivo em gramíneas tropicais. PUBVET, Londrina, V. 8, N. 13, Ed. 262, Art. 1743, Julho, 2014.

plantas forrageiras com vistas a maximizar a eficiência de colheita da forragem produzida.

O acúmulo de biomassa na pastagem após a desfolhação é resultante do fluxo de elaboração de novos tecidos foliares, definido como produção primária, e do fluxo de senescência e decomposição de tecidos foliares mais antigos. Com o aparecimento de novas folhas e perfilhos na pastagem após a desfolhação, aumenta a competição por luz, nutrientes, água e demais fatores do meio, intensificando-se o processo de senescência e morte das folhas e perfilhos mais velhos.

Assim, a senescência pode ser acelerada por ação dos fatores de meio ou, ainda, decorrer espontaneamente do vencimento da duração de vida da folha ou do perfilho. A pastagem atinge, então, o número máximo de folhas vivas por perfilho, havendo equilíbrio entre o surgimento e a morte de folhas. Ao se analisar diferentes sistemas de manejo é importante enfatizar a diferença entre a produção potencial e a produção colhível, em que a primeira é estimada pela fotossíntese líquida do relvado, enquanto a segunda decorre da primeira, após descontadas as perdas por senescência e a alocação de assimilados para o crescimento de colmos e raízes (Parsons et al., 1988).

O alongamento de colmos e a densidade de perfilhos são as variáveis morfogênicas e estruturais mais afetadas pela intensidade e sucessão dos pastejos (desfolhas). As condições ambientais têm maior influência sobre as características morfogênicas e estruturais em comparação a ações de manejo, como manipulação da oferta de forragem. Ofertas de forragem de $4 \%$ do $\mathrm{PV} /$ dia promovem menor alongamento de colmo e tendem a reduzir as perdas por senescência (Casagrande et al., 2010).

Os perfilhos, após atingirem a maturidade, tendem a assumir um número relativamente constante de folhas verdes e a maturidade, desencadeia fenômenos fisiológicos que determinam o processo de senescência (Hodgson, 1990).

A maioria dos compostos solúveis podem ser transportados e reutilizados em outras partes da planta quando esta se encontra no estágio inicial da 
SIMIONI, T.A. et al. Senescência, remoção, translocação de nutrientes e valor nutritivo em gramíneas tropicais. PUBVET, Londrina, V. 8, N. 13, Ed. 262, Art. 1743, Julho, 2014.

senescência, mas a maior parte dos componentes celulares são utilizados na respiração da folha e de bactérias e fungos que vivem sobre o tecido vegetal. No processo de senescência a folha perde cerca de $50 \%$ de seu peso, e quando morta e seca acaba caindo e incorporada ao solo. O mesmo que acontece com folhas pode acometer os perfilhos, sendo a senescência de perfilhos como um todo mais comum quando o tecido meristemático é cortado ou pastejado (Hodgson, 1990). Além disso, o processo de senescência varia conforme a época do ano e fatores de ambiente (Gomide, 1997).

Existe uma relação direta entre a altura do pasto e a taxa de senescência. Quanto maior a massa de forragem, maior o IAF e, conseqüentemente, maiores as taxas de crescimento que, contudo, estão associadas a maiores perdas por senescência (Hodgson, 1990). De acordo com Pinto (2000), a competição por luz pode levar algumas plantas à morte devido à grande mobilização de carbono pela respiração. Nessas condições, uma maior quantidade de assimilados é alocada para o crescimento de perfilhos já existentes em detrimento do desenvolvimento de novos perfilhos, quando em situação de sombreamento. Contudo, quando em condições de disponibilidade limitada de luz, os perfilhos novos são os primeiros a morrer como consequência da sobreposição e do sombreamento causados por perfilhos maduros.

O crescimento e a senescência operam em perfilhos individuais (Pinto, 2000) e, quando avaliados num todo, determinam a produção da comunidade vegetal (Da Silva \& Pedreira, 1997). Do ponto de vista fisiológico, o fluxo de tecidos pode ser melhor compreendido quando se considera o perfilho como uma seqüência de fitômeros cada qual seguindo estágios pré determinados de desenvolvimento, desde primóridos foliares até órgão maduro e, finalmente, senescência (Gomide, 1997).

A senescência abrange todos os processos de deterioração que acompanham o envelhecimento e que conduz a morte de um órgão ou da planta toda. Esse processo pode ocorrer devido a fatores climáticos (geada ou seca) ou ao mal manejo de pastagens, uma vez que o crescimento da mesma 
SIMIONI, T.A. et al. Senescência, remoção, translocação de nutrientes e valor nutritivo em gramíneas tropicais. PUBVET, Londrina, V. 8, N. 13, Ed. 262, Art. 1743, Julho, 2014.

ocorre de modo contínuo, e dentro de condições favoráveis, de modo rápido, permitindo que a biomassa excedida não seja totalmente pastejada pelos animais (Humphreys, 1991).

Segundo Hodgson (1990), a curva de acúmulo de forragem em uma pastagem apresenta três pontos bem definidos, uma primeira fase onde o acúmulo é lento, uma segunda de intenso crescimento, e uma terceira, onde a taxa de acúmulo tende a zero e o dossel atinge o valor-teto de acúmulo. De acordo com Lemaire \& Chapman (1996), numa fase inicial o balanço entre crescimento e senescência é positivo uma vez que as folhas que senescem são aquelas que nasceram primeiro, e têm tamanho menor. Além disso, ocorre uma defasagem de algumas semanas entre o aparecimento e a senescência das primeiras folhas de mais baixo nível de inserção, gerando um saldo positivo adicional, além do maior tamanho das folhas mais novas (Gomide \& Gomide, 1999).

Após algum tempo, a taxa de senescência se iguala à taxa de aparecimento de folhas, ficando o número de folhas verdes por perfilho constante, próprio para cada espécie ou cultivar. As folhas que surgem passam a ter o mesmo tamanho ou até mesmo tamanho inferior ao das anteriores. Nessa situação, a taxa de acúmulo de forragem cai para zero, ou em condições extremas, pode tornar-se negativa caso a quantidade de material senescente aumente demasiadamente (Parsons et al., 1988). Segundo Brougham (1956, 1958), a máxima taxa de acúmulo líquido ocorreria quando um pasto em rebrota atingisse a interceptação de $95 \%$ da luz incidente (Figura 9 e 10). 
SIMIONI, T.A. et al. Senescência, remoção, translocação de nutrientes e valor nutritivo em gramíneas tropicais. PUBVET, Londrina, V. 8, N. 13, Ed. 262, Art. 1743, Julho, 2014.

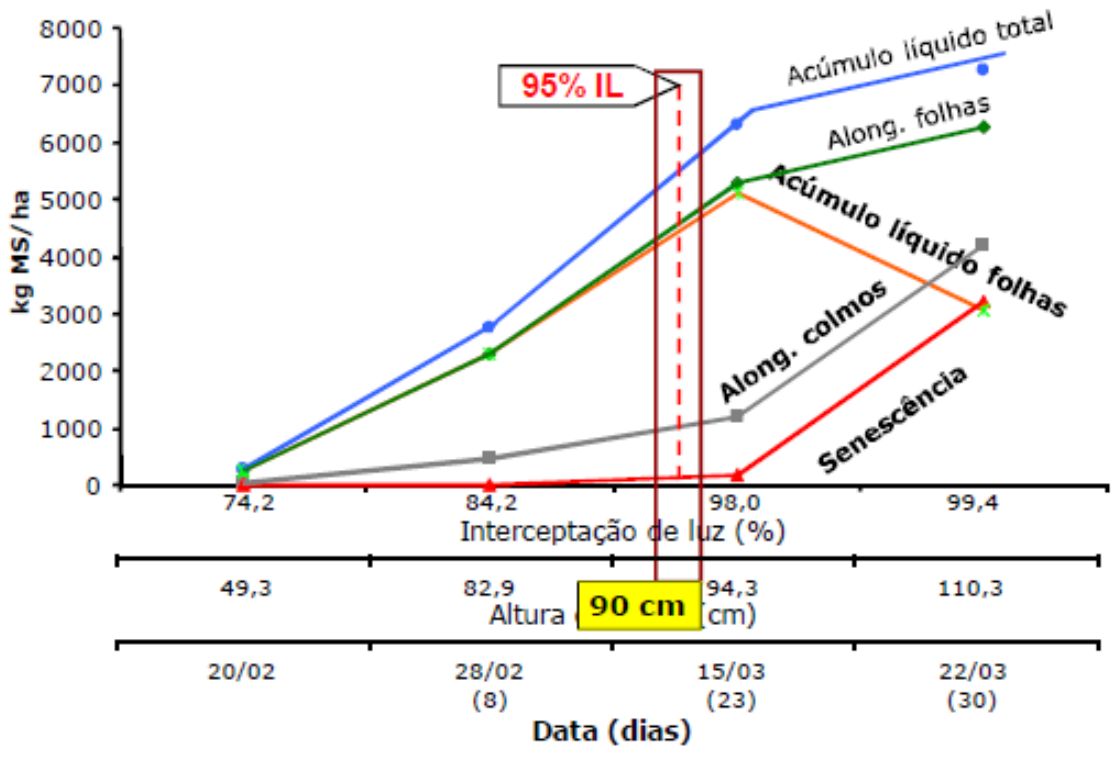

Figura 9 - Acumulo liquido total; Alongamento de folhas; Acumulo liquido de folhas; Alongamento de colmos e Senescência em pasto de Capim-mombaça (Carnevalli, 2003).

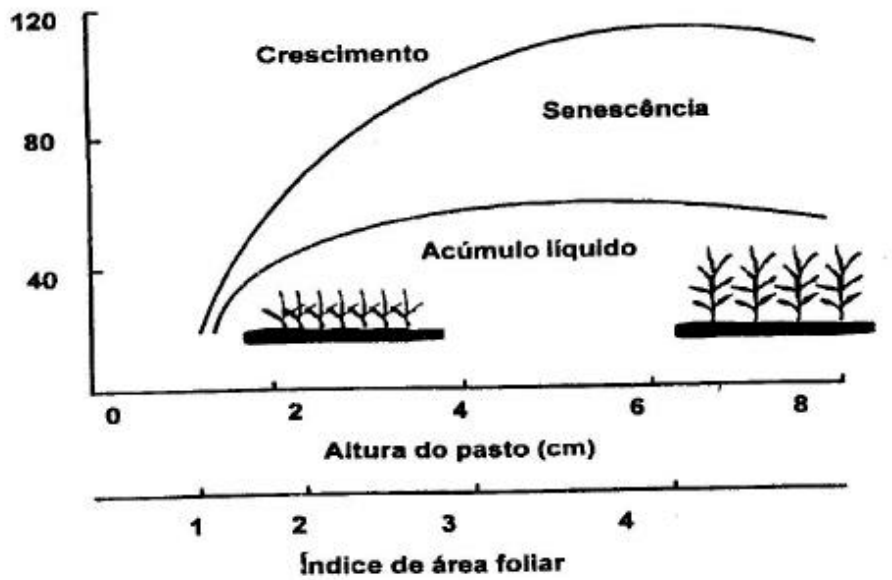

Figura 10 - Influência da estrutura do pasto (altura e IAF) sobre as taxas de crescimento, senescência e acúmulo líquido de forragem. Adaptado de Hodgson (1990). 


\section{IMPORTÂNCIA PARA O DESEMPENHO ANIMAL}

A produção animal em pastagens pode ser entendida como um processo de três fases: crescimento da planta forrageira, utilização da forragem e sua conversão em produto animal (Figura 11) (Hodgson, 1990).

Um dos principais objetivos com o manejo do pastejo é fazer com que a maior parte da forragem consumida pelo animal seja composta por lâminas foliares.

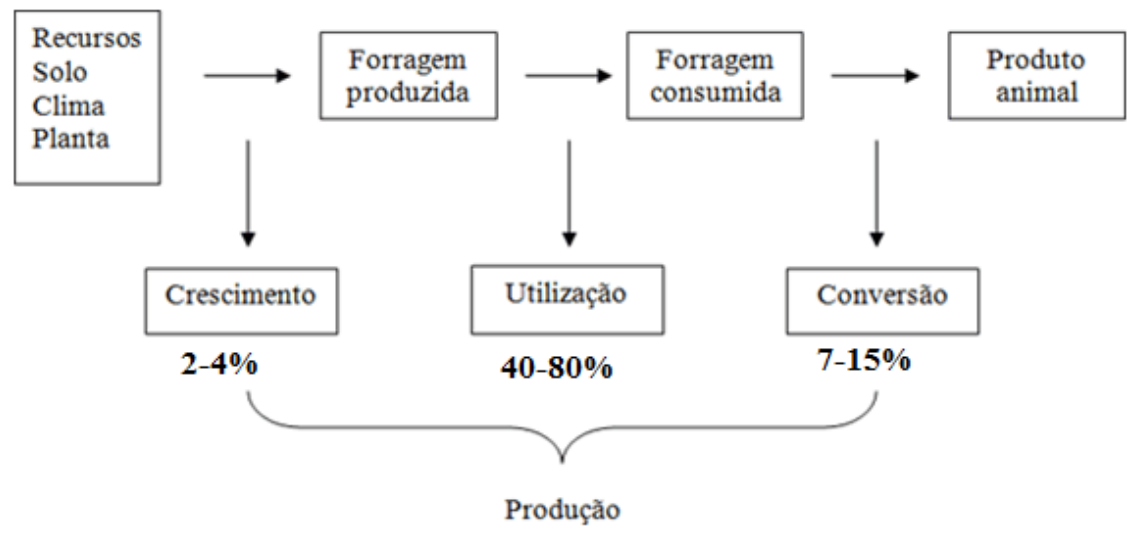

Figura 11 - Representação esquemática dos estágios de produção em em ecossistemas de pastagens (Adaptado de Hodgson, 1990).

Em sistemas de produção baseados em forragens como a única fonte de nutrientes, o desempenho dos animais pode ser menor que o determinado geneticamente e, ou o desejado para satisfazer os objetivos da produção, uma vez que a eficiência máxima de utilização da dieta resulta do fornecimento de dietas balanceadas nutricionalmente e o desempenho animal é limitado a aquele suportado pelo nutriente primeiro limitante (NRC, 2001).

Sistemas de produção animal a pasto são baseados na manipulação de fatores de meio, da planta e do animal, de forma a gerar um equilíbrio dinâmico entre o suprimento de alimento (acúmulo de forragem e forragem conservada) e a demanda por esse alimento (requerimentos individuais $x$ número de animais/área) (Da Silva \& Pedreira, 1997). Assim, o manejo da pastagem tem por objetivo principal o comprometimento de, ao mesmo tempo, manter área foliar fotossinteticamente ativa e permitir que os animais 
SIMIONI, T.A. et al. Senescência, remoção, translocação de nutrientes e valor nutritivo em gramíneas tropicais. PUBVET, Londrina, V. 8, N. 13, Ed. 262, Art. 1743, Julho, 2014.

colham grandes quantidades de tecido foliar de alta qualidade antes que esse material entre em senescência.

Como a produção de folhas é prioridade na alimentação, para o bom manejo, é necessário conhecer e compreender não apenas o processo de transformação do pasto (forragem) em produto animal, mas sobretudo entender e controlar os processos de crescimento e desenvolvimento que resultam na produção da forragem a ser consumida. Dessa forma, quando se entende a dinâmica de crescimento e desenvolvimento das plantas que compõem uma pastagem e suas respostas morfofisiológicas aos fatores que as influenciam, torna-se mais fácil adequar o manejo do pasto visando à sustentabilidade do sistema de produção com alta produtividade dos componentes planta e animal, respeitando os limites ecofisiológicos das plantas forrageiras (Nascimento Júnior \& Adese, 2004).

Os entraves da produção animal baseada no uso d plantas forrageiras tropicais podem, em parte, ser reduzidos por meio de práticas de manejo que aumentem a produção e a eficiência de utilização do pasto.

$\mathrm{Na}$ busca pela correta condução dos animais em pastejo, é de grande importância o conhecimento do processo de transformação da forragem em produto animal e, principalmente, da dinâmica dos processos de crescimento e desenvolvimento das plantas que compõem a pastagem e suas respostas morfofisiológicas aos fatores interferentes. Entre esses fatores, destaca-se a intensidade de pastejo, que afeta diretamente as taxa de acúmulo de forragem (Parsons et al., 1983).

A intensificação do sistema de produção com o uso de animais de elevado potencial produtivo tem aumentado a demanda por alimentos de melhor qualidade e em maior quantidade. Neste sentido, o manejo de pastagens tem como objetivo principal obter, por unidade de área, a máxima produção de forragem de satisfatório valor nutritivo, durante a estação de pastejo, gerando um grande paradoxo, de atender às exigências nutricionais dos animais e às exigências fisiológicas das plantas, para que a produção não seja afetada. Isso quer dizer que os animais precisam consumir forragem de 
SIMIONI, T.A. et al. Senescência, remoção, translocação de nutrientes e valor nutritivo em gramíneas tropicais. PUBVET, Londrina, V. 8, N. 13, Ed. 262, Art. 1743, Julho, 2014.

alta qualidade para atingir os níveis de produção desejados e as plantas dependem dessas folhas para manter sua eficiência fotossintética.

Segundo Nascimento Jr (1986), os fracassos quanto à persistência de plantas forrageiras são, possivelmente, devido à não observância do comportamento fisiológico das espécies em uso.

A produção de matéria seca nada mais é que o resultado final, líquido e efetivo de uma série de eventos ecofisiológicos na comunidade de plantas forrageiras, e que não representa produção animal potencial alguma se não for relacionada à variável consumo (somente possível quando o animal se faz presente), principal determinante da qualidade e, ou, valor alimentício de uma dada forragem (Silva et al., 1997).

Se relacionarmos então, a pressão de pastejo com a reação da pastagem, podemos analisar o que acontece com as plantas, ou seja, qual a sua resposta à intensidade de desfolhação. Em outras palavras, o que acontece com o IAF e seus reflexos sobre a captação de luz e consequentemente sobre a taxa de crescimento e senescência da pastagem. Pode-se então utilizar de um parâmetro que relaciona diretamente a fisiologia vegetal e que permite controlar a oferta e regular a resposta da pastagem à eficiência de consumo desta oferta pelo animal.

Para o uso de pastagens intensivas na produção animal uma das práticas de manejo que devem ser utilizadas, é a reposição de nutrientes, a fim de se manter elevadas as produções de matéria seca e com a devida qualidade. Desse modo, esperam-se bons desempenhos individuais e por área, que devem variar conforme a espécie da forrageira utilizada (Tabela 8).

Normalmente, a aplicação de nutrientes em pastagem, de forma geral, incrementa significativamente a produção da forragem, cerca de 2 meses após a aplicação, podendo ter efeito residual importante no crescimento da planta após 2 anos da aplicação (Whitehead, 2000). Assim, diferentemente da agricultura, a eficiência da adubação na pecuária é medida não apenas pela produção vegetal (grãos;biomassa), mas também pela capacidade de produção 
SIMIONI, T.A. et al. Senescência, remoção, translocação de nutrientes e valor nutritivo em gramíneas tropicais. PUBVET, Londrina, V. 8, N. 13, Ed. 262, Art. 1743, Julho, 2014.

de carne por unidade de nutriente aplicado. Assim, na pecuária, a avaliação da eficiência da adubação torna-se mais complexa, por conter o fator animal.

Tabela 8 - Taxas de ganho de peso diário e ganho de peso vivo por ha/ano de animais pastejando em algumas gramíneas tropicais.

\begin{tabular}{|c|c|c|c|c|c|c|}
\hline & \multicolumn{2}{|c|}{ Adubação } & \multirow[t]{2}{*}{ Lotação } & \multicolumn{2}{|c|}{ Ganho animal } & \multirow[b]{2}{*}{ Período } \\
\hline Pastagem & $\begin{array}{c}\text { Estabeleciment } \\
\text { o }\end{array}$ & $\begin{array}{c}\text { Manutenç } \\
\text { ão }\end{array}$ & & $\begin{array}{c}\text { g/cab./ } \\
\text { dia }\end{array}$ & $\begin{array}{l}\text { Kg/há/ } \\
\text { ano }\end{array}$ & \\
\hline B. brizantha & Sem & Sem & 2,2 & 357 & 290 & $1983 / 89$ \\
\hline B. brizantha & Sem & Sem & 2,8 & 273 & 320 & 3 ciclos \\
\hline B. decumbens & $\mathrm{Ca}, \mathrm{P}$ e K & Sem & 2,5 & 380 & 345 & 3 anos \\
\hline B. decumbens & $\mathrm{Ca}, \mathrm{P}$ e $\mathrm{K}$ & Sem & 2,4 & 395 & 345 & 3 anos \\
\hline Colonião & $\mathrm{Ca}, \mathrm{P}$ e $\mathrm{K}$ & Sem & 2,1 & 420 & 325 & 3 anos \\
\hline Tobiatã & Ca, P e K & Sem & 2,5 & 450 & 415 & 3 anos \\
\hline Tanzânia-1 & $\mathrm{Ca}, \mathrm{P}$ e $\mathrm{K}$ & Sem & 2,3 & 520 & 445 & 3 anos \\
\hline B. humidicola & $\mathrm{Ca}, \mathrm{P}$ e $\mathrm{K}$ & Sem & 3 & 475 & 406 & 330 dias \\
\hline $\begin{array}{l}\text { B. humidicola }+ \\
\text { D. ovalifolium }\end{array}$ & $\mathrm{Ca}, \mathrm{P}$ e $\mathrm{K}$ & Sem & 3 & 540 & 462 & 330 dias \\
\hline $\begin{array}{l}\text { B. humidicola }+ \\
\text { P. phabrooloides }\end{array}$ & $\mathrm{Ca}, \mathrm{P}$ e $\mathrm{K}$ & Sem & 3 & 525 & 430 & 330 dias \\
\hline Tanzânia - 1 & $\mathrm{Ca}, \mathrm{P}$ e $\mathrm{K}$ & Sem & 4,6 & 423 & 711 & 2 anos \\
\hline Tanânia - 1 + N & $\mathrm{Ca}, \mathrm{P}$ e $\mathrm{K}$ & Sem & 5,2 & 363 & 682 & 2 anos \\
\hline Monbaça & $\mathrm{Ca}, \mathrm{P}$ e $\mathrm{K}$ & Sem & 6 & 376 & 825 & 2 anos \\
\hline $\begin{array}{l}\text { B. brizantha } \\
\text { B. brizantha }\end{array}$ & $\mathrm{Ca}, \mathrm{P}$ e K & Sem & 2,5 & 337 & 354 & 414 dias \\
\hline $\begin{array}{l}75 \%+\text { Leucena } \\
25 \%\end{array}$ & $\mathrm{Ca}, \mathrm{P}$ e $\mathrm{K}$ & Sem & 2,5 & 401 & 422 & 414 dias \\
\hline & & & Médias de & & & 2 anos \\
\hline $\begin{array}{l}\text { Capim -elefante } \\
\text { anão }\end{array}$ & $\mathrm{Ca}, \mathrm{N}, \mathrm{P}$ e $\mathrm{K}$ & Sem & $\begin{array}{c}4 \\
\text { pressões }\end{array}$ & 979 & 1.110 & $\begin{array}{c}\text { (out/abr } \\
\text { ) }\end{array}$ \\
\hline
\end{tabular}

Adaptado de Zimmer; Euclides Filho (1997). 
SIMIONI, T.A. et al. Senescência, remoção, translocação de nutrientes e valor nutritivo em gramíneas tropicais. PUBVET, Londrina, V. 8, N. 13, Ed. 262, Art. 1743, Julho, 2014.

Independentemente da estratégia ou do sistema de produção a ser adotado, a eficiência bioeconômica da adubação na produção animal depende da eficiência agronômica ( $\mathrm{kg}$ de matéria seca $/ \mathrm{kg}$ de nutriente aplicado), da eficiência de pastejo, a relação da forragem produzida que é consumida pelo animal, dada em porcentagem; e a eficiência de conversão alimentar, ou seja, a eficiência do animal em converter em carne a forragem consumida $(\mathrm{kg}$ matéria seca de forragem $/ \mathrm{kg}$ ganho de peso vivo). Assim, os resultados das três eficiências indicam a eficiência do nutriente aplicado como fertilizante, em produto animal. Desse modo, observa-se que apenas eficiência agronômica, ou seja, a maior oferta de forragem não garante maior retorno da atividade pecuária. Assim, é importante considerar todo o processo pós-produção da forragem até a conversão em carne.

Existe uma relação da disponibilidade de forragem e o ganho de peso de animais (Paulino, 2004). Esse autor verificou que os maiores ganhos diários foram de $500 \mathrm{~g}$ e $580 \mathrm{~g}$, e as disponibilidades de MSV de $1000 \mathrm{~kg} \mathrm{ha}-1$ e $900 \mathrm{~kg}$ ha-1, respectivamente, para Brachiaria e Panicum (Figura 12).

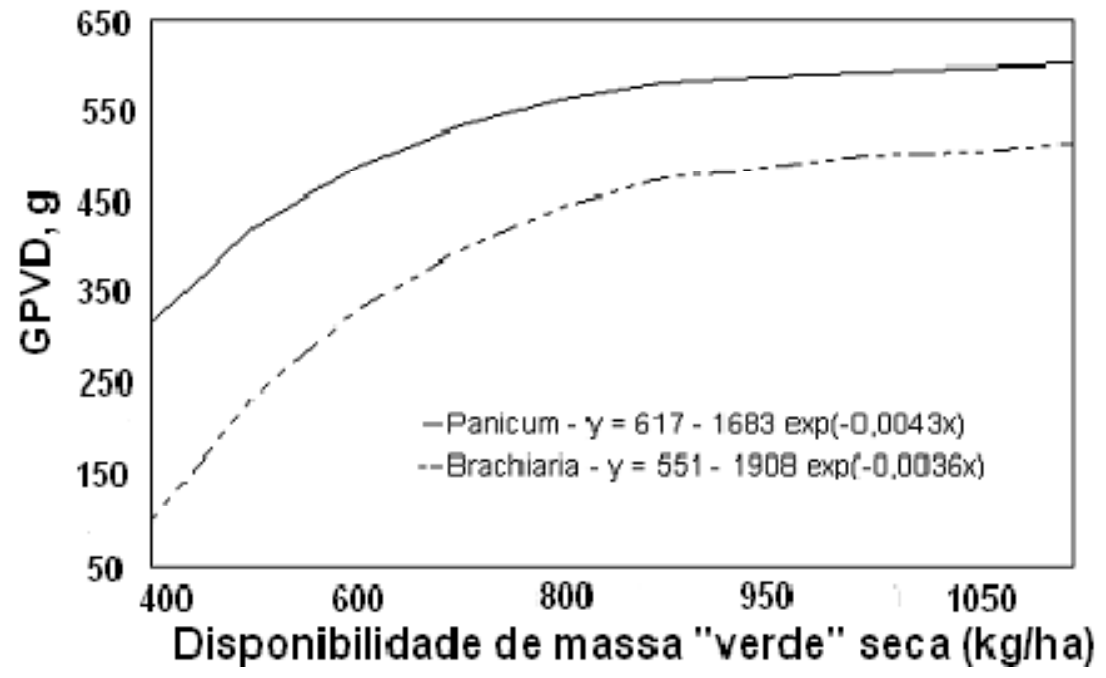

Figura 12 - Ganhos de peso vivo diários (GPVD) em função da disponibilidade de matéria verde seca $\left(\mathrm{kg} \mathrm{ha}^{-1}\right)$ (Whitehead, 2000). 
É conhecido que valores inferiores a 7\% de proteína bruta na forragem provocam diminuição no consumo de matéria seca das mesmas pelos animais (Milford \& Minson, 1966) em razão de maior tempo de retenção do material no rúmen, devido a uma significativa redução na digestibilidade da matéria seca por deficiência de nitrogênio para as bactérias. E é conhecido que os teores de FDN da forragem são negativamente correlacionados ao seu consumo, especialmente em material constituído com mais de $55-60 \%$ de parede celular na matéria seca (Van Soest, 1994), o que pode afetar o desempenho do animal. Quanto melhor for a qualidade da forrageira, maiores ganhos de peso são obtidos por animal e menor oferta de forragem é necessária.

$\mathrm{Na}$ exploração racional, é relevante que a pastagem apresente persistência e alta produção, para que o animal possa expressar o seu potencial genético com a utilização de forragens de alto valor nutritivo (Peternelli, 2003).

\section{CONCLUSÕES}

A produção de forragem, entendida como o balanço líquido entre a síntese de novos tecidos e a perda de tecidos por senescência e morte, pode ser influenciada positiva ou negativamente por um mesmo fator, dependendo da combinação, espécie-ambiente. O valor nutritivo das gramíneas que se desenvolvem em condições de clima tropical é limitado, não somente pela incidência das elevadas temperaturas, que promovem mais intensa lignificação da parede celular, mas também por características histológicas e anatômicas inerentes à estas gramíneas.

O ponto chave no manejo de pastagens é, conseguir equilibrar a conflitante demanda por área foliar (fotossíntese) e a remoção de tecidos para o consumo animal, que é predominantemente constituído por folhas. Assim, torna-se importante conhecer não só o comportamento dos animais, mas também da planta forrageira. Maiores pesquisas devem se concentrar na resposta fisiológica em fluxo de tecidos das plantas forrageiras sob diversos 
SIMIONI, T.A. et al. Senescência, remoção, translocação de nutrientes e valor nutritivo em gramíneas tropicais. PUBVET, Londrina, V. 8, N. 13, Ed. 262, Art. 1743, Julho, 2014.

fatores ambientais, para que as pastagens tenham sua produtividade assegurada.

\section{REFERÊNCIAS BIBLIOGRÁFICAS}

ANDRADE, I. F., GOMIDE, J. A. Curva de crescimento e valor nutritivo de do Capim-Elefante (Pennisetum purpureum Schum) "A-146 Taiwan". R. Ceres, v.18, n.100, p.431-447, 1971.

BEADLE, C.L. Growth analysis. In: HALL, D.O.; BOLHARNORDENKAMPF, H.F.; LEEGOOD, R.C. (Eds.) Photosynthesis and production in a chaging environment. London: Pergamon Prees, 1993. p.36-45.

BENETT, C.G.S. Produtividade e composição bromatológica do capimmarandu a fontes e doses de nitrogênio. Ilha Solteira, 2007. 48 p. Dissertação (mestrado) - Universidade Estadual Paulista. Faculdade de Engenharia de Ilha Solteira.

BOVAL, M.; CRUZ, P.; LEDET, J.E.; COPPRY, O.; ARCHIMEDE, H. Effect of nitrogen on intake and digestibility of a tropical grass grazed by Creole heifers. Journal of Agricultural Science, v.138, 73-84, 2002.

BRÂNCIO, P. A., NASCIMENTO JÚNIOR, D. , et al. , Avaliação de três cultivares de Panicum maximum JACQ. Sob pastejo: composição da dieta, consumo de matéria seca e ganho de peso animal. Revista Brasileira de Zootecnia, v.32, p. 1037-1044, 2003.

BRISKE, D.D. Developmental morphology and physiology of grasses. In: HEITSCHMIDT, R.K., STUT H, J.W. (Eds.) Grazing management: an ecological perspective. Portland: Timber Press, 1991. p.85-108.

CARNEVALLI, C.A. Dinâmica da rebrotação de pastos de capim Mombaça submetidos a regimes de desfolhação intermitente. Piracicaba, 2003. 136 p. Tese (Doutorado) - Escola Superior de Agricultura "Luiz de Queiroz", Universidade de São Paulo.

CECATO, U.; GOMES, L.H.; ASSIS, M.A. et al. Avaliação de cultivares do gênero Cynodon. In: REUNIÃO ANUAL DA SOCIEDADE BRASILEIRA DE ZOOTECNIA, 33., 1996, Fortaleza. Anais... Fortaleza: Sociedade Brasileira de Zootecnia, 1996. p.114-116.

CHAPMAN, D.F.; ROBSON, M.J.; SNAYDON, R.W. Quantitative carbon distribution in clonal plants of white clover (Trifolium repens): source - sink relationship during undisturbed growth. The Journal of Agricultural Science. v.116, n.2, p.229-238, $1991 \mathrm{~b}$.

CHAPMAN, D.F.; ROBSON, M.J.; SNAYDON, R.W. The influence of leaf position and defoliation on the assimilation and translocation of carbon in white clover (Trifolium repens L.). 1. Carbon distribution patterns. Annals of Botany, v.67, n.4, p.295-302, 1991a.

CLIFFORD, P.E.; MARSHALL, C.; SAGAR, G.R. The reciprocal transfer of radiocarbon between a developing tiller and its parent shoot in vegetative plants of Lolium multiflorum Lam. Annals of Botany, v.37, n.152, p.777-785, 1973.

CORSI, M., BALSALOBRE, M.A., SANTOS, P.M. et al. Bases para o estabelecimento do manejo de pastagens de braquiária. In: SIMPÓSIO SOBRE MANEJO DA PASTAGEM, 1994, Piracicaba. Anais... Piracicaba: ESALQ-USP, 1994. p.249-266. 
CORSI, M.; NASCIMENTO JÚNIOR, D. Princípios de Fisiologia e Morfologia de Plantas Forrageiras Aplicados no Manejo das Pastagens. In: Pastagens - Fundamentos da Exploração Racional. FEALQ. p. 15-47, 1994.

DA SILVA, S.C.; PEDREIRA, C.G.S. Princípios de ecologia aplicados ao manejo de pastagem. In: SIMPÓSIO SOBRE ECOSSISTEMAS DE PASTAGENS, 3., Jaboticabal, 1997. Anais... Jaboticabal: Funep, 1997. p. 1-12.

DALE, J. E. The growth of leaves. London: Edward Arnold, 1982. 60p. (Studies in Biology, 137).

DAVIES, A. The regrowth of grass swards. In: JONES, M.B.; LAZENBY, A. (Eds.) The grass crop. London: Chapman and Hall, 1988. p. 85-127.

DURU, M.; DUCROCQ, H. Growth and senescence of the successive leaves on a Cocksfoot tiller. Effect of nitrogen and cutting regime. Annals of Botany, v.85, p.645-653, 2000.

EASTIN, J. D.; SULLIVAN C.Y. Environmental stress influences on plant persistence physiology, and production. In.: TESAR, M. B. Physiological basic of crop growth and development. Madison: American Society of Agronomy, cap. 8, p. 201-236, 1984.

EPSTEIN, E.; BLOOM, A. Nutrição mineral de plantas: princípios e perspectivas. 2a Ed. Maria Edna Tenório Nunes (Tradutora). Londrina: Editora Planta, 2006.403p.

EUCLIDES, V.B.P. Valor alimentício de espécies forrageiras do gênero Panicum. In: SIMPÓSIO SOBRE MANEJO DE PASTAGENS, 12, 1995, Piracicaba. Anais... Piracicaba: FEALQ, p.245-273, 1995.

EUCLIDES, V.P.B. Alternativas para intensificação da produção de carne bovina em pastagem. Campo Grande: Embrapa Gado de Corte,65p, 2000.

EUCLIDES, V.P.B.; MACEDO, M.C.M.; VIEIRA, A.; OLIVEIRA, M.P.de. Valores nutritivos de cinco gramíneas sob pastejo. In: REUNIÃO ANUAL DA SOCIEDADE BRASILEIRA DE ZOOTECNIA, 32., 1996, Fortaleza. Anais... Fortaleza: SBZ, p.90-92, 1996.

EVANGELISTA, A. R., Formação e manejo de pastagens tropicais, UFLA, Lavras - v.1, p.7. MG, p. 5-45, 2000.

FABRICIO, J.A. Produtividade e composição bromatológica do capim - Tobiatã em função da adubação NPK. Ilha Solteira, 2007. 56p. Dissertação (mestrado) - Universidade Estadual Paulista. Faculdade de Engenharia de Ilha Solteira.

FRANCISCO, E.A.B. Antecipação da adubação da soja na cultura de Eleusine coracana (L.). Gaertn., em sistema de plantio direto. 2002. 58p. Dissertação (Mestrado) - Escola Superior de Agricultura Luiz de Queiroz, USP.

FULKERSON, W.J., SLACK, K. 1995. Leaf number as a criterion for determining defoliation time for Lolium perenne. 2. Effect of defoliation frequency and height. Grass and Forage Sci., $50(1): 16-20$.

GABELMAN, W.H. \& GERLOFF, G.C. The search for and interpretation of genetic controls that enhance plant growth under deficiency levels of a macronutrient. Plant Soil, v.72,p.335-350, 1983. 
GOMIDE, C.A.M., GOMIDE, J.A. Morfogênese e análise de crescimento de cultivares de Panicum maximum In: REUNIÃO ANUAL DA SOCIEDADE BRASILEIRA DE ZOOTECNIA, 33, 1996, Fortaleza. Anais... Fortaleza: SBZ, 1996. p. 403-405.

GOMIDE, J.A. Fisiologia e manejo de plantas forrageiras. Revista da Sociedade Brasileira de Zootecnia, Viçosa, v. 2, p. 17-26. 1973.

GOMIDE, J.A. Morfogênese e análise de crescimento de gramíneas tropicais. In: SIMPÓSIO INTERNACIONAL SOBRE PRODUÇÃO ANIMAL EM PASTEJO, Viçosa, 1997. Anais... Viçosa: UFV, 1997b. p. 411-429.

GOMIDE, J.A.. Fisiologia do Crescimento Livre de Plantas Forrageiras. In: Pastagens Fundamentos da Exploração Racional. FEALQ. p. 1-14, 1994.

GOMIDE, J.A.; GOMIDE, C.A.M. Fundamentos e estratégias do manejo de pastagens. In: SIMPÓSIO DE PRODUÇÃO DE GADO DE CORTE, Viçosa, 1999. Anais... Viçosa: UFV, p.179200, 1999.

HODGSON, J. Grazing management: science into practice. New York: John Wiley e Sons, 1990. 203p.

HODGSON, J; BIRCHAM, J.S.; GRANT, S.A.; KING, J. The influence of cutting and grazing management on herbage growth and utilization. In: Occasional Symposium, 13., British Grassland Society, 1981. p. $51-62$.

HUMPHREYS, L. R., Tropical pasture utilisation. Cambridge University Press, 1991. 205.

JACQUES, A.V.A. Caracteres morfo-fisiológicos e suas implicações com o manejo. In: CARVALHO, M. M.; ALVIM, M. J.; XAVIER, D. F. (Eds.). Capim-elefante: produção e utilização. Coronel Pacheco: EMBRAPACNPGL, 1994. p. 331-47.

JACQUES, A.V.A. Fisiologia do crescimento de plantas forrageiras. In: SIMPÓSIO SOBRE MANEJO DA PASTAGEM, 1., Piracicaba, 1973. Piracicaba: FEALQ, 1973. p. 95-101.

JEWISS, O.R. Morphological and physiological aspects of growth of grasses during the vegetative phase. In: MILTHORPE, F.L., IVINS, J.D. (Ed.) The growth of cereals and grasses. London: Butterworths, 1966. p.39-56.

JONES, M. B. \& WOODMANSEE, R.G. Biogeochemical cycling in annual grassland ecosystems. Botany Review, v.45,n.2,p.111-144, 1979.

JOOST, R.E. Nutrient cycling in forrage systems. In: JOOST, R.E; ROBERTS, C.A. (Eds.) Nutrient cycling in forage systems. Columbia: Misouri, 1996. p. 1-12.

KLEPPER, B.; BELFORT, R.K., RICKMAN, R.W.. Root and shoot development in winter wheat. Agronomy Journal, v.76, n.1, p.117-122, 1984.

KORTE, C.J.; HARRIS, H. Effects of grazing and cutting. In: SNAYDON, R.W. (Ed.) Managed grasslands - Analytical studies ecosystems of the world, v. 17-B. Amsterdam: Science Publishers B.V., 1987. p 71-79.

LANGER, R.H.M. Tillering in herbage grasses. Herb. Abstr., v.33, n.3, p.141-148, 1963.

LARCHER, W. Physiological plant eccology. 3.ed. Berlin: Springer-Verlag, 1995. 506p. 
LAVEZZO, W.; SILVEIRA, A.C.; GONÇALVES, D.A. et al. Efeito da idade da planta ao primeiro corte sobre a produção, composição bromatológica e alguns aspectos morfológicos de Brachiaria decumbens (S.). Revista Brasileira de Zootecnia, v.9, p.656-672,1980.

LEMAIRE, G.; AGNUSDEI, M. Leaf tissue turnover and efficiency of herbage utilization. In: GRASSLAND AND ECOPHYSIOLOGY AND ECOLOGY, 1999, Curitiba. Anais...Curitiba: Universidade Federal do Paraná, 1999. p.165-186.

LEMAIRE, G.; CHAPMAN, D. Tissue flows in grazed plant communities. In: HODGSON, J.; ILLIUS, A.W. (Eds.) The ecology and management of grazin systems. Wallingford: Cab International, 1996. p.3-36.

MACEDO, M.C.M. Degradação de pastagens; conceitos e métodos de recuperação In: "SUSTENTABILIDADE DA PECUÁRIA DE LEITE NO BRASIL". Anais..., Juiz de Fora. P.137$150,1999$.

MACHADO, R.C.R., SOUZA, H.M.F.; MORENO, M.A.; ALVIM, P.T. Variáveis relacionadas com a tolerância de gramíneas forrageiras ao déficit hídrico. Pesquisa Agropecuária Brasileira, v. 18, n.6, p. 603-608, 1983.

MAGALHÃES, R.T.; OLIVEIRA, I.P.; KLIEMANN, H.J. Relações da produção de massa seca e as quantidades de nutrientes exportados por Brachiaria brizantha em solos sob o manejo pelo sistema "barreirão". Pesquisa Agropecuria Tropical, v.32,n.1,p.13-20, 2002.

MATCHES, A.G. Influence of intact tillers and height of stubble on growth responses of Tall fescue. Crop Science, v.6, n.5, p.484-487.1966.

MATTHEW, C.; KEMALL, W.D. Allocation of carbon14 to roots of different ages in perennial ryegrass ( Lolium perenne L.), In: GRASSLAND CONGRESS, 18., 1997, Manitoba/ Saskachewan. Proceedings... Manitoba/Saskachewan: 1997.

MILTHORPE, F. L.; DAVIDSON, J. L. Physiological aspects of regrowth in grasses. In: MILTHORPE, F. L.; IVINS (Eds.) The growth of cereals and grasses, 1966, p. 241-254.

MOORE, K.J., MOSER, L.E., VOGEL, K.P., WALLER, S.S., JOHNSON, B.E., PEDERSEN, J.F. Describing and quantifying growth stages of perennial forage grasses. Agron. J., v.83, n. 6, p.1073-1077, 1991.

MORENO, L.S.B. Produção de forragem de capins do gênero Panicum e modelagem de respostas produtivas e morfofisiológicas em função de variáveis climáticas. Dissertação (Mestre em Ciência Animal). Escola Superior de Agricultura 'Luiz de Queiroz', Piracicaba, 2004.

NASCIMENTO JUNIOR, D.; ADESE, B. Acúmulo de biomassa na pastagem. In: SIMPÓSIO SOBRE MANEJO ESTRATÉGICO DA PASTAGEM, 2., 2004, Viçosa, MG. Anais... Viçosa, MG: Universidade Federal de Viçosa, 2004. p.289-330.

NASCIEMNTO JÚNIOR, D. do. Leguminosas - Espécies Disponíveis, Fixação de Nitrogênio e Problemas Fisiológicos para o Manejo de Consorciação. In: Simpósio sobre Manejo da Pastagem, 8, Piracicaba. Anais... Piracicaba : FEALQ p. 390-411, 1986.

NASCIMENTO JÚNIOR, D.; QUEIROZ, D.S.; SANTOS, M.V.F. Degradação das pastagens e critérios para avaliação. In: Peixoto, A.M.; Moura, J.C.; Faria, V.P. (eds.). SIMPÓSIO SOBRE MANEJO DE PASTAGEM, 11, Piracicaba, 1994. Anais... Piracicaba: FEALQ, 325p, 1994. 
PARSONS, A.J.; JOHNSON, J.R.; WILLIAMS, J.H.H. Leaf age structure and canopy photosynthesis in rotationally and continuously grazed swards. Grass and Forage Science, $v$. 43, n. 1, p. 1-14, 1988.

PARSONS, A.J.; LEAFE, E.F.; COLLET, B. et al. The physiology of grass production undergrazing: 2- Photosynthesis, crop growth and animal intake of continuosly grazed swards. Journal of Applied Ecology, v.20, n.1, p.127-139, 1983.

PAULINO, V.T. Potencialidade de pastagens tropicais para produção animal. 1Palestra proferida no Simpósio de Produção Animal a Pasto no Norte Pioneiro, abril/2004.

PETERNELLI, M. Características morfogênicas e estruturais do capim-braquiarão [Brachiaria brizantha (Hochst ex A. Rich.) Stapf. cv. Marandu] sob intensidades de pastejo. Pirassununga: Universidade de São Paulo, 2003. 79p. Dissertação (Mestrado em Zootecnia) - Universidade de São Paulo, 2003.

PINTO, J.C. Crescimento e desenvolvimento de Andropogon gayanus Kunt, Panicum maximum Jacq. e Setaria anceps Stapf ex Massey cultivadas em vasos, sob diferentes doses de nitrogênio. Viçosa, MG: UFV, 1993. 149p. Tese (Doutorado em Zootecnia) - Universidade Federal de Viçosa, 1993.

PINTO, L.F.M. Dinâmica do acúmulo de matéria seca em pastagens de Cynodo spp. Piracicaba, 2000. 124p. Dissertação (Mestrado) - Escola Superior de Agricultura "Luiz de Queiroz", Universidade de São Paulo.

POPPI, D.P.; HUGHES, T.P.; L'HUILLIER, P.J. Intake of pasture by grazing ruminants. In: LIVESTOCK FEEDING ON PASTIURE. New Zealand Society of Animal Production, Occasional Symposium, 10, Hamilton, 1987. Anais... Hamilton: Lincoln College, p. 55-63.

RAVEN, P.H., EVERT, R.F., EICHHORN, S.E. Biologia Vegetal. Ed. Gunabara Koogan S.A., Rio de Janeiro, 2001, 906p.

REIS, R.A.; RODRIGUES, L.R.A. Valor nutritivo de plantas forrageiras. Jaboticabal. FUNEP, 1993. 26p.

REIS, S.T. Valor nutricional de gramíneas tropicais em diferentes idades de corte. Lavras, 2000. 99p. Dissertação (Mestrado) - Universidade Federal de Lavras.

ROBSON, M.J.; RYLE, G.J.A.; WOLEDGE, J. The grass plant - its form and function. In: JONES, M.B.; LAZENBY, A. (Eds.) The grass crop. London: Chapman \& Hall Ltda, 1988. p.25-83.

RODRIGUES, A.L.P., SAMPAIO, I.B.M., CARNEIRO, J.C.; TOMICH, T.R.; MARTINS, R.G.R. Degradabilidade in situ da matéria seca de forrageiras tropicais obtidas em diferentes épocas de corte. Arquivo Brasileiro de Medicina Veterinária e Zootecnia, v.56, n.5, p.658-664, 2004.

RODRIGUES, L. R. de A.; RODRIGUES, T. de J. D. Ecofisiologia de plantas forrageiras. In: CASTRO, P. R. C. et al. (Eds.) Ecofisiologia da produção Agrícola. Anais...Piracicaba: POTAFOS, 1987. p. 203-230.

RYLE, G.J.A. A comparison of leaf and tiller growth in seven perennial grasses as influenced by nitrogen and temperature. J. Brit. Grassl. Soc., v.19, n.3, p.281-290, 1964. 
RYLE, G.J.A. Distribution pattern of assimilated $14 \mathrm{C}$ in vegetative and reproductive shoots of Lolium perenne and L. temulentum. Annals of Applied Biology, v.66, n.97, p.155-167, 1970b.

RYLE, G.J.A. Partition of assimilates in an annual and a perennial grass. Journal of Applied Ecology, v.7, n.1, p.217-227, 1970a.

RYLE, G.J.A.; POWELL, C. E. The export and distribution of 14C-labelled assimilates from each leaf on the shoot of Lolium temulentum during reproductive and vegetative growth. Annals of Botany, v.36, n.145, p.363-375, 1972.

RYLE, G.J.A.; POWELL, C.E. The utilization of recently assimilated carbon in graminaceous plants. Annals of Applied Biology, v.77, n.2, p.145-158, 1974.

SANTOS, P.M.; BALSALOBRE, M.A. et al. Características morfogenéticas e taxa de acúmulo de forragem do capim Mombaça submetido a três intervalos de pastejo. Revista Brasileira de Zootecnia, v.33, n.4, p.843-851, 2004.

SCHNYDER, H.; DE VISSER, R. Fluxes of reserve-derived and currently assimilated carbon and nitrogen in perennial ryegrass recovering from defoliation. The regrowing tiller and its component functionally distinct zones. Plant Physiology, v.119, n.2, p.1423-1435, 1999.

SILVA, S.C., Condições edafo-climáticas para a produção de Panicum. In.: Simpósio sobre manejo de pastagem, 12., Piracicaba, 1995. Anais... Piracicaba: FEALQ, p. 129- 146, 1995.

SORIA, L. G. T., Produtividade de capim Tanzânia (Panicum maximum Jacq cv. Tanzânia) em função da lâmina de irrigação e de adubação nitrogenada. Tese (Doutorado em Agronomia - Escola Superior de Agricultura Luiz de Queiroz, Piracicaba, 2002.

SOUZA, D.M.G.; VILELA, L.; REIN, T.A.; LOBATO, E. Eficiência da adubação fosfatada em dois sistemas de cultivo em um Latossolo de Cerrado. In: CONGRESSO BRASILEIRO DE CIÊNCIA DO SOLO, 26., 1997. Rio de Janeiro. Anais. Rio de Janeiro: SBCS, 1997.

SOUZA, F. H. D. Produção de sementes de gramíneas forrageiras tropicais. São Carlos: Embrapa Pecuária Sudeste, 2001. 43 p. (Documentos, 30).

TAIZ, L.; ZEIGER, E. Translocation in the phloem. In: TAIZ, L.; ZEIGER, E. (Eds.) Plant physiology. 2.ed. Sunderland: Sinauer Associates, 1998. p.251-259.

VALLENTINE, J.F., Grazing management. San Diego: Academic Press, 533p, 1990.

VAN SOEST, P.J. Nutritional ecology of the ruminant. New York: Cornell University Press, 1994. 476p.

VRIES, D.M., HOOGERS, B.J. Distribution of tillers of plant species in old permanent grassland with different types of use. Neth. J. Agric. Sci., v.7, p.232-236, 1959.

WALLER, S.S., MOSER, L.E., REECE, P.E. Understanding grass growth: the key to profitable livestock production. Kansas City: Trabon Printing, 1985.

WARD, C. Y.; BLASER, R. E. Carboydrate Food Reserves and Leaf Area in Regrowht of Orchardgrass. Crop Science, v. 1, p. 366-370. 1961.

WHITEHEAD, D.C. Nutrient Elements in Grassland Soil-Plant-Animal Relationships. CAB International Publishing. Wallingford, Oxon, UK, 2000. 
WILHELM, W.W., MCMASTER, G.S. Importance of the phyllochron in studying development and growth in grasses. Crop Sci., v.35, n.1, p.1-3, 1995.

WOLEDGE, J. The effect of age and shade on the photosynthesis of white clover leaves. Annals of Botany, v.57, n.2, p.257-262, 1985.

WOLEDGE, J. The effect of light intensity during growth on the subsequent rate of photosynthesis of leaves of tall fescue (Festuca arundinacea Schreb). Annals of Botany, v.35, n.140, p.311-322, 1971.

ZELITCH, I. The close relationship between net photosynthesis and crop yield. BioScience, v.32, n.10, p.796-802, 1982.

ZIMMER, A.H., EUCLIDES, V.P.B., MACEDO, M.C.M. Manejo de Plantas do Gênero Brachiaria. In: Simpósio sobre Manejo de Pastagem, 9, Piracicaba, 1988. Anais... Piracicaba : FEALQ. p. 142-183, 1988. 